\title{
Numerical simulation analysis of anchorage characteristics of constant-resistance and large- deformation anchor cable for highly weathered rock masses
}

\section{Tao Zhigang ( $\sim$ taozhigang@cumtb.edu.cn )}

China University of Mining and Technology beijing https://orcid.org/0000-0002-1966-3678

\section{Deng Fei}

China University of Mining and Technology - Beijing

\section{WANG Zhicai}

Gansu Changda Highway Co.Ltd

\section{QIAO Xiaobing}

Gansu Provincial Highway Aviation Tourism Investment Group co.Ltd

\section{Mengnan}

China University of Mining and Technology Beijing

\section{Xu Shengxin}

Deformation Survey Center, Yunnan Earthquake Agency

\section{Case study}

Keywords: Slope, NPR anchor cable, FLAC3D, numerical simulation, anchorage length, anchorage characteristics

Posted Date: April 24th, 2020

DOI: https://doi.org/10.21203/rs.3.rs-23674/v1

License: (c) (1) This work is licensed under a Creative Commons Attribution 4.0 International License. Read Full License 


\section{Abstract}

In order to effectively maintain the stability of high and steep loose slopes around the site of the Tonglushan Ancient Copper Mine in Daye City, Hubei Province, the NPR anchor cable reinforcement system was introduced. Based on the significance of anchorage characteristics of NPR anchor cable for the whole reinforcement system, we first investigated and analyzed the engineering geological conditions of the ancient smelting site slopes, while selected a typical highly weathered section to establish a numerical simulation calculation model. Following, utilized the FLAC3D method to numerically calculate the reinforcement effect of NPR anchor cables under various anchorage lengths. Finally, based on the calculation results, we reveal the changes in displacement, as well as in stress and anchor cable axial force of the site slope, analyzing the shear strain rate and evolution characteristics of plastic zone near the potential sliding surface. The calculation results show that as the NPR anchorage length increase, the displacement gradually decrease. Moreover, the maximum axial force of the NPR anchor cable and the principal stress of the slope change slightly, while the plastic failure range gradually decrease; when the anchorage length is $20 \mathrm{~m}$, the safety factor reach the peak value and the reinforcement effect is optimal, which lay the theoretical and practical foundation for the reinforcement control of similar site slopes.

\section{Introduction}

The factors affecting slope stability are numerous and complex, while the major disaster-causing factors that induce landslides under various environmental conditions significantly differ(Fan et al.2019; Zhang et al. 2019; Xie et al.2019). It has been discovered that slope stability evaluation and reinforcement research are interdisciplinary disciplines. At present, a high number of control measures have been proposed both domestically and abroad for the instantaneous and slow large-scale deformation of slopes. Lattice beams, ordinary anchors and anti-sliding piles, have been used to ensure rock mass stability and engineering safety (Wang et al.2019; Li et al.2014; Song et al.2018). However, regarding traditional strengthening conditions, as the rock deformation and soil structure increase, damages to reinforcements occur, such as reinforcement bolts / cables breakage or deformation, while the anchorage exits the rock formation (Guo et al.2015). This would eventually lead to the reinforcement system complete failure and induce local or overall collapse of slopes (Tao et al. 2018a; Tao et al. 2017; Jing et al. 2019). In response to the aforementioned problems, an NPR anchor cable capable of deformation energy absorption was successfully developed by He Manchao. Subsequently, it was successfully utilized for mine disaster monitoring, early warning and control. In 2010, the NPR anchor cable was applied to the field of landslide monitoring by He Manchao, to achieve the integration of landslide monitoring, reinforcement, prevention, monitoring, and early warning (Chen et al. 2011; Tao et al. 2011). In 2015, it was verified that the NPR anchor cable had excellent adaptability to dynamic impact during impact tensile testing. Moreover, this was verified through finite element analysis(He et al.2015;Li et al.2015). In terms of negative Poisson's ratio effect of the NPR anchor cable, it was verified that it had improved dynamic impact resistance compared to traditional anchors through physical experimentation by Li Chen et al (Li C et al. 2016). In 2016, the idea of NPR anchor cable and rock mass was theoretically proposed 
and verified by He Manchao in the NPR anchor cable supporting principle and large deformation control technology (He et al. 2016). Tao Zhigang conducted combined lab experiments and numerical simulations to establish an energy equation for the interaction among NPR anchors / cables and surrounding rock masses. Subsequently, the mechanical changes and energy absorption characteristics of NPR anchors / cables throughout surrounding rock control were revealed (Tao et al. 2018b); in 2018, Lv Qian verified that NPR anchor cable had good mechanical properties, demonstrating a certain negative Poisson's ratio effect through static tensile experimentation (Lv 2018 a, b). In 2009, Tao Zhigang et al. conducted numerical simulation analysis to prove for the NPR anchor $r$ setting as constant resistance and energy absorption process (Tao et al. 2020).

In summary, NPR anchor cables have been intensively studied in current researches on the working principles, characteristics, the negative Poisson ratio effect of materials, impact dynamics analysis, finite element analysis, disaster control principles and static tension. However, for the influence of the NPR anchor cable structure parameters on the anchoring characteristics and even for the analysis of control variables through numerical simulation, for which, the special research was still non-existent.

\section{Analysis Of Engineering Geological Characteristics Of Highly Weathered Slopes At Smelting Sites Of Ancient Copper Mine}

\subsection{Project case}

Daye Tonglushan Ancient Copper Mine Smelting Site was located in Daye City, Southeast of Hubei Province. The ancient site mining area was approximately square in shape and covered an area of approximately $7.8 \mathrm{~km}^{2}$. The site terrain was dominated by hills and lake basins, while surrounded by water from three sides during the flood season. The site was mainly composed of the No. $\otimes$ body, located at the middle of the site. Archeologically, this part was composed of numbered five sites (Figure 1). With the intensification of open-pit mining activities at the west side of the site, a large open-pit mining pit had gradually formed at the west side, accompanied by random mining and excessive excavation, worsening the surrounding geological conditions. In August 2006, disasters of geological environment, such as ground cracks and wall deformation began to occur within the museum area, while a series of measures, such as ground crack filling and anchor cable reinforcement, were adopted. However, according to the onsite monitoring determination, the slope deformation was still intensely high. In 2013, cracks occurred inside and outside of the museum, accompanied by intensified extensions (Figure 2).

\subsection{Analysis on formation lithology characteristics}

According to the comprehensive strength values of rocks, the site strata could be divided into five types of engineering geological rocks: loose rock, weak rock, weaker rock, harder rock and hard rock (Table 1).

Table 1: Main stratigraphic features of ore bodies 


\begin{tabular}{|c|c|c|c|}
\hline Rock & Stratum position & Main composition & Strength \\
\hline Loose rock & Surface stratum & $\begin{array}{l}\text { Quaternary eluvium and deluvium, Artificial filled } \\
\text { soil, Pile of mine }\end{array}$ & Low \\
\hline Weak rock & Beneath surface stratum & Strongly weathered diorite porphyry & $\begin{array}{l}\text { Little } \\
\text { low }\end{array}$ \\
\hline $\begin{array}{l}\text { Little weak } \\
\text { rock }\end{array}$ & $\begin{array}{l}\text { Intrusive rock of middle } \\
\text { stratum }\end{array}$ & skarn & General \\
\hline $\begin{array}{l}\text { Little strong } \\
\text { rock }\end{array}$ & Middle stratum & $\begin{array}{l}\text { Moderately weathered diorite porphyry and } \\
\text { partial marble }\end{array}$ & $\begin{array}{l}\text { Little } \\
\text { high }\end{array}$ \\
\hline Strong rock & Lower part of stratum & $\begin{array}{l}\text { Marble complete rock, Weakly weathered diorite } \\
\text { porphyry }\end{array}$ & High \\
\hline
\end{tabular}

The ore body VII, which affected the slope stability, was divided along several main sliding surfaces to produce geological section models towards different directions.

\subsection{Analysis of Geological Structure Features}

The south of the mining area comprised a series of compression structures, composed of near-west linear folds and compressive fracture. The latest stratum participating within the fold constituted the Lower Triassic Daye Group. There are wide-spread folds and tightly-packed anticlines. The north wing of the anticline mostly turned northbound and tilted southbound. Therefore, the southern part of the study area was a relatively uplifted area of caprock folds.

The north tectonic line NWW was composed of a series of discontinuous anticlines and synclines. Due to the NNE trending structure influence, local NNE trending folds occurred. NNE-, NWW- and NE faults developed and caved. Also, the "Mesozoic fault depression basins" was formed, which had deposited newer strata from the Middle Triassic upon Quaternary. Therefore, the northern part of study area was a relatively depressed area with caprock folds.

In summary, based on the Indosinian folds, the Daye concave fold fault bundles further evolved into the structural pattern, which was uplifted on the south and caved towards the north, through the movements of Yanshan and Xishan.

\subsection{Hydrogeological conditions}

Site stratigraphic classification could be divided into permeable layer, aquifer, and aquifuge from top to bottom. The main source of recharge was rainfall; the aquifer was shallow rock and soil and artificial surface deposits, which generally have poor water permeability. Aquifer groundwater tables were high towards the east and low towards the west, forming groundwater runoff, while demonstrating apparent seasonal changes; groundwater maintained a certain water level height, while the flow direction was from east to west.

\section{Analysis Of Landslide Body Characteristics And Failure Mechanism}




\subsection{Landslide characteristics}

The main unstable areas of the site slope were located at the upper and lower areas of Highway 3, which were divided into landslides No. 1 and No. 2 (Figure 3). The No. 1 landslide was composed of the northsouth landslide group at the west side of the site. It was located north of the upper part of the No. 3 highway with an inclination angle of approximately forty degrees, while the main landslide headed west. It was mainly composed of loose artificial soil and slag and the Quaternary soil layer, while the relatively strong diorite porphyry group formed the sliding bed. The No. 2 landslide was located below the No. 3 highway and distributed above the open-pit mining pit at the west side of the site. The shape was a large sector shape. The slope was $16 \mathrm{~m}$ long and $60 \mathrm{~m}$ wide, while the pitch was $60^{\circ}$ from the horizontal direction. The landslide area was approximately $958 \mathrm{~m}^{2}$ and the volume was approximately $990 \mathrm{~m}^{3}$.

\subsection{Analysis of landslide failure mechanism}

According to the analysis of the landslide body characteristics and engineering geological characteristics, it was known that the landslide body was damaged, due to the interaction among internal and external factors.

Internal factors included: (1) High slopes on the west due to open-pit mining. (2) The upper soil layer in the landslide area was fractured and loose, while the water permeability was high; the lower layer of the landslide area had poor water permeability and high strength. The boundary of the soil layer was clearly delimited. (3) The rock formations within the mining area contained joints and fissures, which had high water absorption, also easily affected by rainfall and groundwater.

External factors included: (1) Rainfall during the rainy season in Dazhi area was high. (2) Crushed slag and rock produced through artificial mining on top of the slope. (3) Due to the blasting vibration within the mining area, the slope of site further slipped.

Therefore, the landslide body was formed in two steps.

(1) First step: The landslide body was caused to sink by the blasting vibration and historical goaf during mining and production activities near the site, but the deformation and displacement were relatively low, the slope body still had significant strength, without large-scale fissure penetration occurrence or slip;

(2) Second steps: the soil layer of slope body was compacted due to vibration, which caused the further slope body subsidence, while the scale became larger. The trailing edge of the slope was pulled and multiple cracks were generated at the trailing edge, for which, the width gradually increased, while it was penetrated. Also, body slippage occurred at the slip surface (Figure 5.)

\section{Numerical Simulation Analysis Of Npr Cable Anchorage Characteristics}

4.1 Model construction and optimization of calculation methods 


\subsubsection{Model construction}

Based on the engineering geological analysis of the ancient copper mine site slope in Tonglushan, Daye, 7 sections were selected along the mining area of the site and comparative analysis was carried out. Finally, section $\mathrm{C}$ was determined to be typical, located in-between landslides No. 1 and No. 2. The section $\mathrm{C}$ analysis could better reveal the evolution of the entire slope, which was representative.

According to the location map of each section in Figure 6, section $\mathrm{C}$ was approximately perpendicular to the slope as a whole, for which, the inter-platform span was larger, while this section significantly reflected the formation composition and geological structure. Section $\mathrm{C}$ was selected as the main research object. According to the engineering geological and relevant survey data, the geological composition and stratigraphic distribution of section $\mathrm{C}$ were analyzed, while the strata of the calculation model was divided into 4 layers (Figure 7).

The relationship between the model and the original sizes of $c-c$ 'section was 1:1. The X-axis length was $380 \mathrm{~m}$, the $\mathrm{z}$-axis height was $135 \mathrm{~m}$ and the $\mathrm{Y}$-axis was $50 \mathrm{~m}$. The numerical simulation calculation generalization model was established, as presented in Figure 8.

\subsubsection{Calculation parameter selection}

Based on the integrated analysis of laboratory physical experimentation data and combined with practical engineering experience, the parameters of rock and soil mass were selected by analogy, as presented in Table 2.

Table 2. The permeability coefficient of rock and earth mass

\begin{tabular}{llll}
\hline Geotechnical category & $\begin{array}{l}\text { Porosity } \\
(\square)\end{array}$ & $\begin{array}{l}\text { Saturation permeability } \\
\text { coefficient } \llbracket \mathrm{m} / \mathrm{s})\end{array}$ & $\begin{array}{l}\text { Initial volumetric moisture } \\
\text { content }(\square)\end{array}$ \\
\hline $\begin{array}{l}\text { Quaternary } \\
\text { stratigraphic soil }\end{array}$ & 26.4 & $1.412 \times 10-3$ & 10.8 \\
\hline
\end{tabular}

\begin{tabular}{llll}
\hline Strongly weathered diorite porphyry & 18.6 & $1.404 \times 10-3$ & 12 \\
Moderately weathered diorite porphyry & 16 & $3.528 \times 10-5$ & 11 \\
Weakly weathered diorite porphyry & 8 & $3.321 \times 10-5$ & 18 \\
\hline
\end{tabular}

Referring to relevant survey reports and geological data for physical and mechanical parameters, Table 3 was produced. 
Table 3. Rock-soil body mechanics parameters

\begin{tabular}{|c|c|c|c|c|c|}
\hline \multirow[t]{2}{*}{ Stratum lithology } & \multirow[t]{2}{*}{$\begin{array}{l}\text { Unit weight } \\
\mathrm{KN} / \mathrm{m} 3\end{array}$} & \multicolumn{2}{|c|}{ Cohesion C/Mpa } & \multicolumn{2}{|c|}{$\begin{array}{l}\text { Angle of internal friction } \\
\varphi /{ }^{\circ}\end{array}$} \\
\hline & & Crude & Saturated & Crude & Saturated \\
\hline Quaternary stratigraphic soil & 20.0 & 0.032 & 0.028 & 24 & 24 \\
\hline $\begin{array}{l}\text { Strongly weathered diorite } \\
\text { porphyry }\end{array}$ & 25.5 & 0.05 & 0.045 & 32 & 20 \\
\hline $\begin{array}{l}\text { Moderately weathered diorite } \\
\text { porphyry }\end{array}$ & 27.0 & 6.1 & 5.4 & 50 & 36 \\
\hline Weakly weathered diorite porphyry & 28.5 & 0.30 & 0.25 & 33.0 & 31 \\
\hline
\end{tabular}

In this work, parameters were selected through laboratory experiments, combined with the empirical value comparisons of similar engineering rock masses, while the physical and mechanical parameters of soil at each layer of the site slope were selected, as presented in Table 4.

Table 4. Rock-soil body mechanics parameters

\begin{tabular}{|c|c|c|c|c|}
\hline Sample & $\begin{array}{l}\text { Quaternary } \\
\text { stratigraphic } \\
\text { soil }\end{array}$ & $\begin{array}{l}\text { Strongly weathered } \\
\text { diorite porphyry }\end{array}$ & $\begin{array}{l}\text { Moderately weathered } \\
\text { diorite porphyry }\end{array}$ & $\begin{array}{l}\text { Weakly weathered } \\
\text { diorite porphyry }\end{array}$ \\
\hline $\begin{array}{l}\text { Unite weight } \\
\square \mathrm{KN} / \mathrm{m}^{3} \square\end{array}$ & 20 & 22.6 & 24.0 & 27.0 \\
\hline Cohesion $\square \mathrm{Kpa} \square$ & 20 & 22 & 28 & 38 \\
\hline $\begin{array}{l}\text { Angle of } \\
\text { internal friction } \\
\square^{\circ}[\end{array}$ & 20 & 24 & 27 & 34 \\
\hline
\end{tabular}

\subsubsection{Solution of initial stress field and selection of initial parameters}

\section{(1) Solution of initial stress field}

The natural stress within the stratum had high influence on the changes of stress, displacement and strain generated by the subsequent disturbance of the model. Prior to numerical simulation solution, the model was established, while the initial parameters and boundary conditions were set for the initial calculation, for the model to reach the initial equilibrium state under the initial ground stress condition.

The isotropic mol-coulomb constitutive model was utilized to calculate the initial ground stress, while the material parameters included density, shear modulus and volume modulus. Simultaneously, only the 
self-weight of the material was considered. In order to avoid the failure of structural elements during calculation, high values were assigned to the parameters in the initial calculation. The calculated results of displacement, stress and shear strain rate are presented in Figure 9.

(2) Initial parameter selection

According to the initial ground stress calculation, the maximum displacement area of slope c-c 'section deformation was mainly located at the upper and lower part of highway No. 3. According to the actual field project, two rows of anchor cables were used for slope reinforcement. The first row was on highway No. 3, while the coordinates of the starting position of drilling hole in the simulation model were $(260,25$, 130). The lower part of highway 3 was the second row and the drilling position was $(210,25,105)$. According to the indoor physical simulation and numerical simulation testing, while combined with the actual engineering application, the relevant values of anchorage characteristics of NPR were selected for study, as presented in Table 5.

Table 5. Stability rating scale

\begin{tabular}{|c|c|c|c|c|}
\hline $\begin{array}{l}\text { Related } \\
\text { parameters }\end{array}$ & $\begin{array}{l}\text { Anchor cable length } \\
\square \mathrm{m} \square\end{array}$ & $\begin{array}{l}\text { The incident } \\
\text { Angle } \square^{\circ} \square\end{array}$ & $\begin{array}{l}\text { Pre-tightening } \\
\text { force } \llbracket t \square\end{array}$ & $\begin{array}{l}\text { Anchorage length } \\
\square \mathrm{m} \square\end{array}$ \\
\hline $\begin{array}{l}\text { Parameter } \\
\text { selection }\end{array}$ & 50 & 20 & 80 & $5 \sim 30$ \\
\hline
\end{tabular}

\subsection{Analysis of Numerical results}

The different anchorage lengths of the NPR cable were selected for numerical simulation, while the anchorage characteristics of the NPR cable under this condition were summarized through the variation characteristics combination of the slope strain field and stress field. The structure composition of NPR anchor cable is presented in Figure 10.

\subsubsection{Change law analysis of displacement field}

Based on the numerical simulation of the total displacement cloud diagram, as well as $\mathrm{x}$-displacement and z-displacement cloud diagrams, the slope displacement change characteristics of the NPR anchor cable under different anchorage lengths were analyzed. Through the effect comparison of slope reinforcements, the influence regularity of different anchorage lengths on slope deformation were obtained.

Figure. 11 presents the cloud diagram of total displacement without reinforcement measures and with different anchorage lengths. In order to reveal the law of displacement evolution, a displacement monitoring point $(X=255, Y=25, Z=80)$ was set within the sensitive sub-area of the reinforced area. 
Total displacement semi-log was regularly distributed on the whole, while stronger displacements were mainly concentrated within the strongly weathered diorite porphyry and weathered diorite porphyry formation. The displacements of weakly weathered diorite porphyry and marble set in strata were low. The minimum displacement was at No.3 highway nearby, while the maximal displacement was located at the lower slope toe. This tallied with the actual situation w. From the total displacement nephogram, for the displacement contour the circular arc was assumed, forming relatively apparent landslide failure surface, for which, the north edge of No. 3 road of the area similarly was taken as the circle center, towards the $X$ positive direction and the $Z$ negative direction. Namely, the displacement increased as the stratum depth increased. The lower boundary of the arc was bounded by the weakly weathered diorite porphyry bedrock and the right by the marble group. The right marble formation and the lower weakly weathered diorite porphyry were penetrated by skarn, while the sliding fracture surface did not have a standard arc shape. Along the color mutation site of the sliding fracture surface, the displacement contour was slightly deflected near the intrusion site, as presented in Figure. 11 (a) (g).

The analysis of the total displacement cloud diagram demonstrated that the total displacement was relatively high, when no reinforcement existed. Following the NPR anchor cable slope reinforcement, the total displacement of the reinforced area apparently decreased, while the reduction range was higher, while the reinforcement effect was more apparent. The change characteristics of total displacement cloud diagram at different anchorage lengths were compared and analyzed. After the slope reinforcement, as the anchorage length increased, the reinforced area total displacement decreased. When the anchorage length was further away from the reinforcement area, the total displacement decreased. According to the total displacement monitoring data obtained from the displacement monitoring points, the corresponding relationship between the total displacement of the stratum in the NPR cable reinforcement area and the anchorage length was obtained (Table 6). The fitting relation curve is presented in Figure 12.

Table 6. Corresponding table of total displacement of reinforced area - anchorage length

\begin{tabular}{|c|c|c|c|c|c|c|c|}
\hline Anchorage length $\square \mathrm{m} \square$ & - & 5 & 10 & 15 & 20 & 25 & 30 \\
\hline Total displacement $\square \mathrm{mm} \square$ & 480 & 430 & 428 & 425 & 422 & 420 & 420 \\
\hline
\end{tabular}

As it could be observed from Figure 12, as the anchorage length increased, the total displacement decreased, the curve tended to be flat, whereas the acceleration decreased. Therefore, the relationship between the reduction rates of total displacement and anchorage length was that the reduction rate of displacement decreased as the anchorage length increased.

4.3.2 Analysis of stress field variation law 
According to the simulation results, in this paper, the axial force cloud diagram of NPR anchor cable, the maximum and minimum principal stress cloud diagram of the slope were analyzed. The axial force change law of NPR anchor cable and the stress change characteristics of the slope under different anchorage conditions were studied. Through the effects comparison of slope reinforcements, the deformation laws of slope and the anchorage characteristics of NPR cable under different anchorage lengths were obtained. In the stress cloud diagram, the positive was tension and negative was pressure.

(1)Analysis of NPR anchor cable axial force distribution characteristics

Two rows of NPR anchor cables, above and below highway No.3, were selected for the study. The axial force cloud diagram is presented in Figure 13.

According to the axial force cloud diagram, the axial force of NPR anchor cable was distributed along the entire length, mainly as tensile stress. The axial force of the outer pallet position was low at approximately $5 \mathrm{kN}$, while the axial force of the free segment along the NPR anchor cable was in the direction of the anchorage segment. The axial force of the free segment did not change significantly and was evenly distributed. When the anchorage segment was approached, the axial force increased abruptly from 0 to the maximum, marked as the red position of the NPR anchor cable within the axial force cloud diagram. Taking the position, where the anchorage segment met the free segment, as the origin, the positive direction was inward along the anchorage segment. The monitoring data obtained are presented in Table 7 12.

Table 7. Corresponding table of axial force along anchoring section with anchorage length of $5 \mathrm{~m}$

\begin{tabular}{llllllll}
\hline Anchorage length $\llbracket \mathrm{m} \square$ & 0 & 0.40 & 1.44 & 2.50 & 3.55 & 4.55 & 5.00 \\
\hline Anchor axial force $\amalg+4 \mathrm{~N} \square$ & 3.00 & 5.00 & 9.93 & 8.00 & 4.00 & 2.00 & 1.50 \\
\hline
\end{tabular}

Table 8. Corresponding table of axial force along anchoring section with anchorage length of $10 \mathrm{~m}$

\begin{tabular}{llllllllllll}
\hline Anchorage length $\square \mathrm{m} \square$ & 0 & 0.60 & 1.71 & 2.66 & 3.63 & 4.69 & 5.72 & 6.75 & 7.81 & 8.76 & 9.59 \\
\hline Anchor axial force $₫ \mathrm{E}+4 \mathrm{~N} \square$ & 1.00 & 5.00 & 9.36 & 7.00 & 5.60 & 4.40 & 3.60 & 2.80 & 2.01 & 1.40 & 1.00 \\
\hline
\end{tabular}

Table 9. Corresponding table of axial force along anchoring section with anchorage length of $15 \mathrm{~m}$

\begin{tabular}{|c|c|c|c|c|c|c|c|c|c|c|c|}
\hline Anchorage length $\square \mathrm{m} \square$ & 0 & 0.50 & 1.52 & 2.54 & 3.55 & 4.48 & 6.64 & 7.96 & 12.10 & 13.54 & 15.01 \\
\hline Anchor axial force $\mathrm{E}+4 \mathrm{~N} \square$ & 0.50 & 5.40 & 9.90 & 8.00 & 6.30 & 5.20 & 3.20 & 2.40 & 1.10 & 0.65 & 0.40 \\
\hline
\end{tabular}


Table 10. Corresponding table of the axial force along the anchoring section with anchorage length of $20 \mathrm{~m}$

\begin{tabular}{llllllllllll}
\hline Anchorage length $\square \mathrm{m} \square$ & 0 & 0.46 & 1.51 & 2.30 & 2.88 & 3.89 & 4.85 & 7.42 & 13.46 & 16.01 & 19.00 \\
\hline Anchor axial force $\mathbb{E}+4 \mathrm{~N} \square$ & 0.00 & 2.00 & 8.76 & 6.60 & 5.00 & 3.60 & 2.65 & 1.50 & 0.80 & 0.50 & 0.23 \\
\hline
\end{tabular}

Table 11. Corresponding table of the axial force along the anchoring section with anchorage length of $25 \mathrm{~m}$

\begin{tabular}{llllllllllll}
\hline Anchorage length $\square \mathrm{m} \square$ & 0 & 0.54 & 1.60 & 2.63 & 3.61 & 4.66 & 8.08 & 10.64 & 14.51 & 18.95 & 24.01 \\
\hline Anchor axial force $\llbracket \mathrm{E}+4 \mathrm{~N} \square$ & 1.00 & 2.00 & 8.47 & 6.55 & 5.20 & 4.20 & 2.20 & 1.40 & 0.83 & 0.35 & 0.15 \\
\hline
\end{tabular}

Table 12. Corresponding table of the axial force along the anchoring section with anchorage length of $30 \mathrm{~m}$

\begin{tabular}{llllllllllll}
\hline Anchorage length $\llbracket \mathrm{m} \square$ & 0 & 0.55 & 1.58 & 2.57 & 3.61 & 5.00 & 6.93 & 10.51 & 21.59 & 26.00 & 28.10 \\
\hline Anchor axial force $\llbracket \mathrm{E}+4 \mathrm{~N} \square$ & 0.50 & 2.00 & 7.99 & 6.50 & 5.20 & 3.80 & 2.30 & 1.01 & 0.40 & 0.23 & 0.13 \\
\hline
\end{tabular}

According to the calculation results presented in Table 7 12, the distribution curve of axial force along the anchorage section of NPR anchor cable was obtained through fitting. The vertical coordinate of the curve was the axial force of the anchorage section, while the horizontal axis was the anchorage section length. The coordinate system was established to obtain the distribution curve of the axial force along the anchorage section, as presented in Figure. 14.

The anchorage length and the maximum axial force value of the anchorage section were extracted and the corresponding relationship is presented in Table 13

Table 13. Corresponding table of maximum axial force - anchoring section

\begin{tabular}{lcccccc}
\hline Maximum axial force $\mathbb{E}+4 \mathrm{~N} \square$ & 9.93 & 9.36 & 9.09 & 8.76 & 8.65 & 7.99 \\
\hline Position of maximum axial force $\llbracket \mathrm{m} \square$ & 1.43 & 1.71 & 1.51 & 1.5 & 1.6 & 1.58 \\
Anchorage length $\square \mathrm{m} \square$ & 5 & 10 & 15 & 20 & 25 & 30 \\
\hline
\end{tabular}


According to the data in Table 13, the maximum axial force of NPR cable gradually decreased as the anchorage length increased. Therefore, the maximum axial force could be reduced through the anchorage length increase within a certain range. The relation curve between the maximum axial force of NPR cable and the anchorage length is presented in Figure 15.

The distribution rule of axial force along the whole length of the cable is presented in Figures14and 15:

1) A concentration area exists within the anchorage section of NPR cable from 0 to $10 \mathrm{~m}$, while the axial force on the cable was relatively concentrated. This produced an approximate normal distribution curve at the positions of 0 to $5 \mathrm{~m}$, while the peak value was relatively high, with the $x$-value of approximately $1.6 \mathrm{~m}$. When the anchorage length was within this length range, the members were prone to yield failure.

2) The anchorage section was at the $10 \mathrm{~m} 20 \mathrm{~m}$ stage, which was in the transition zone. The axial force in this zone was relatively low, while the distribution was not concentrated. The bars generally would not yield to failure. The anchorage length of this region was relatively reasonable;

3) The anchorage section was within the stable zone at the stage of $20 \mathrm{~m} \sim 30 \mathrm{~m}$. The axial force of NPR anchor cable was relatively low and evenly distributed. The cable of this length would not yield and could not be effectively used, resulting in resource waste.

4) As the anchorage length increased, the distribution position of the maximum axial force was basically unchanged, while the axial force at the end afar from the free section was relatively low, with a minimum value of approximately $0.5-1 \mathrm{KN}$;

5) Under different anchorage lengths, the cable sustained the same sliding force. Consequently, the anchorage length increase could not effectively reduce the maximum axial force. Therefore, it was necessary to select a reasonable anchorage length to ensure anti-slip force.

(2) Maximum principal stress variation analysis

The maximum principal stress of the site slope was studied and the cloud diagrams of the principal stresses under different NPR anchor cable reinforcement conditions were analyzed and compared, as presented in Figure $16 \mathrm{a} \sim \mathrm{g}$. The distribution characteristics and changes of maximum principal stress under different conditions were summarized.

Maximum principal stress cloud images revealed the maximum principal stress contour distribution characteristics: Lower tensile stresses were produced at the position where strong upper strata slope, weathering diorite porphyry and marble group were in contact. The maximum tensile stress was approximately + 0.018 MPa. Also, the lower part, mainly by gravity, was given priority to acquire compressive stress, while the size was proportional to the stratum depth. The maximum stress value was approximately $1.472 \mathrm{MPa}$. Under the sliding force action, the slope tended to slide downwards, causing 
tension to the trailing edge of the slope. When the slope was relatively stable, the tension was low. Moreover, stress deflection occurred at the tectonic position of the upper marble and diorite porphyry formation, resulting in stress concentration and in discrete interface.

The relation between the maximum principal stress and anchorage length was summarized as presented in Table 14. The relation curve is presented in Figure 17.

Table 14. Corresponding table of maximum principal stress - anchorage length

\begin{tabular}{lccccccc}
\hline Anchorage length $\llbracket \mathrm{m} \square$ & - & 5 & 10 & 15 & 20 & 25 & 30 \\
\hline Maximum compressive stress (MPa) & -1.4720 & -1.4719 & -1.4719 & -1.4720 & -1.4720 & -1.4719 & -1.4719 \\
Maximum tensile stress (KPa) & +17.699 & +17.711 & +17.711 & +17.703 & +17.704 & +17.711 & +17.713 \\
\hline
\end{tabular}

According to the relationship curve between the maximum principal stress and anchorage length, as the anchorage length increased, the maximum compressive stress first increased and consequently decreased, whereas the maximum tensile stress first decreased and consequently increased. When the anchorage length was approximately $17.5 \mathrm{~m}$, the maximum compressive stress reached the maximum and the maximum tensile stress reached the minimum, slight changes occurred for the quantity values.

In summary, the distribution of main stress changed less when the NPR anchor cable was used for reinforcement than without reinforcement. Moreover, the maximum values of compressive and tensile stresses changed less, which did not produce the expected effect. When the NPR anchor cable was utilized, the stress release within the reinforced area was low, indicating that the maximum main stress of the slope mainly occurred due to the corresponding dead weight, having slight influence upon it after support addition.

(3) Analysis of the minimum principal stress change law

Figure 18 presents the different NPR anchor cable reinforcement under the condition of principal stress variation characteristics, from top to bottom. The principal stress was distributed in layers. The gradient was relatively uniform, differently from the maximum principal stress distribution characteristics case. Slight deflection occurred at the tectonic location of the group of marble and diorite porphyry. In addition, stress concentration occurred, forming discrete structural interface. The failure surface of the landslide was at the middle of the slope and did not run through the entire slope. The minimum principal stress was proportional to the stratum depth, while the compressive stress was approximately $-26.9 \mathrm{KPa} \sim$ $-4.61 \mathrm{mpa}$. With the anchorage length change, the distribution law of minimum principal stress was basically the same, only the surface part of the slope changed significantly. 
The relation between the minimum principal stress and anchorage length is presented in Table 15, while the corresponding fitting relation curve is presented in Figure 19.

Table 15. Corresponding table of minimum principal stress - anchorage length

\begin{tabular}{|c|c|c|c|c|c|c|c|}
\hline Anchorage length $(\mathrm{m})$ & - & 5 & 10 & 15 & 20 & 25 & 30 \\
\hline Maximum compressive stress $\square \mathrm{MPa} \square$ & 4.6090 & 4.6088 & 4.6089 & 4.6090 & 4.6090 & 4.6088 & 4.6088 \\
\hline Minimum compressive stress $₫ \mathrm{kPa} \square$ & 26.834 & 26.916 & 26.885 & 26.849 & 26.846 & 26.877 & 26.868 \\
\hline
\end{tabular}

As it could be observed from the relation curve between the minimum principal stress and anchorage length, as the anchorage length increased, the maximum compressive stress first increased and consequently decreased, while the minimum stress first decreased and consequently increased. When the length of the anchorage section of the curve was approximately $17.5 \mathrm{~m}$, the maximum value of compressive stress significantly increased, while the minimum value significantly decreased. The minimum compressive stress was mainly distributed at the rear edge of the landslide.

In summary, the distribution characteristics of minimum principal stress were deduced. The minimum principal stress was stratified from top to bottom within the strata, which was roughly proportional to the depth, resulting in stress concentration at the tectonic site. Simultaneously, following the NPR anchor cable reinforcement application, no effective stress release occurred within the reinforcement area, while the slope stress was still dominated by gravity.

\subsubsection{Analysis of shear strain rate and plastic zone characteristics}

The analysis of landslide mode and mechanism demonstrated that when the slope slid, mainly shear failure occurred, while shear stress rapidly changed and stress concentration occurred at the landslide rupture surface location. Shear strain rate was high and plastic deformation area was formed. Based on the results of numerical simulation, the variation characteristics of shear strain rate and plastic zone were analyzed, while the anchorage characteristics of NPR cable without reinforcement measures and different anchorage lengths were extracted.

(1) Variation characteristics of shear strain rate

According to the numerical simulation results, the cloud diagram of shear strain rate under different anchorage lengths was analyzed (Figure.20). The slope of the site was in a relatively unstable state, due to the disturbance of production and rainfall at the mining area, along with the corresponding weak layer and sliding fissure zone. 
The shear strain rate cloud diagram revealed the following rules: An apparent landslide failure surface occurred inside the slope, which was approximately circular, while the shear strain rate was concentrated on the slope foot, where the shear position was when the slope presented slip. The shear strain rate at the contact point between the marble formation and the diorite porphyry formation significantly increased, indicating that the shear stress at the contact point of the slope changed significantly with a slide trend.

Fig. 20 presents the comparison of shear strain rate changes under different conditions: without reinforcement measures, the shear strain rate was relatively high at the slope foot, extending along the rupture towards the upper part and gradually decreasing; it became higher near the structure, gradually decreasing at the upper slope surface. The shear strain rate of the middle part of the slope apparently decreased, compared to the middle part of the slope without reinforcement.

According to the shear strain rate cloud diagram of the slope with different anchorage lengths, the following rules could be obtained: as the anchorage length increased, the location of the sliding crack surface gradually shifted to the stratum lower interior. Moreover, the sliding crack surface area gradually expanded, forming a large and dispersed landslide fracture surface. However, the maximum shear strain rate at the slope foot decreased as the anchorage length increased, indicating that the reinforcement effect was relatively apparent. Based on the relationship between maximum shear strain rate and anchorage length, the anchorage characteristics were extracted.

The maximum value of shear strain rate was analyzed, as presented in Table 16. Subsequently, the relationship curve among maximum and minimum values of shear strain rate and anchorage length was obtained through fitting, as presented in Fig. 21.

Table 16. Corresponding table of shear strain rate - anchorage length

\begin{tabular}{llllllll}
\hline Anchorage length $\square \mathrm{m} \square$ & - & 5 & 10 & 15 & 20 & 25 & 30 \\
\hline Maximum shear strain rate(+E-6) & 4.4372 & 4.2710 & 4.3067 & 4.5508 & 4.5160 & 3.9483 & 4.2692 \\
Maximum shear strain rate(+E-15) & 25.739 & 31.750 & 1.5319 & 31.517 & 3.1192 & 19.826 & 9.0161 \\
\hline
\end{tabular}

Fig. 21 presents that as the anchorage length increased, the maximum value of shear strain rate first increased, followed by decrease and increase, demonstrating an overall decreasing trend. When the anchorage length was $25 \mathrm{~m}$, the reduction was apparent. When the anchorage length was $25 \mathrm{~m}$, the shear strain rate was relatively low, combined with the maximum variation law of shear strain rate, the slope reinforcement effect was improved, when the anchorage length was $25 \mathrm{~m}$.

(2) Characteristic analysis of plastic zone 
According to the numerical simulation results, the plastic zone cloud diagram when the slope was reinforced with anchorage of different lengths, was obtained, as presented in Fig. 22 (a) (g).

Analysis of plastic zone cloud diagram: plastic deformation occurred at the slip crack surface, while the edge and the bottom slope foot were darker in color, resulting in a high degree of plastic deformation, simultaneous representing shear deformation failure and tensile deformation failure. The slip crack surface was more prone to failure than other parts of the slope, which was consistent with landslide failure pattern. Analysis was carried out from the foot of the slope to the top of the slope along the slide crack: (1) the plastic deformation at the slope foot was mainly shear deformation and tensile deformation, while a low range of tensile deformation at could be observed at the upper part of the slope foot. (2) upwards, along the slope foot, shear and tension failures occurred within most areas of the sliding crack surface. The lower skarn penetrated the slope middle and the plastic zone distributions on both sides of the edge of the slip crack surface expanded irregularly. The plastic zone near the top of the slope mainly sustained shear and tensile failures, which extended to both sides of the sliding crack surface and gradually formed a plastic deformation zone, dominated by tensile failure with a gradually expanded range. (3) when the slope surface was reached, the shear failure had completely changed to the tensile deformation failure and the scope was high. Due to the joint structure formed by the marble formation and the diorite porphyry formation, the contact area presented a relatively discrete plastic deformation boundary.

The plastic deformation laws of slope under different anchorage lengths were compared and analyzed: the slope foot faced upwards along the slip crack and the plastic zone at the slope foot shrank as the anchorage length increased. At the lower part of slope, the failure was transformed into only one failure mode through the combined action of shear stress and tension, while the new plastic failure zone was significantly reduced in size. According to the plastic zone cloud diagram, when the anchorage length was $25 \mathrm{~m}$, the plastic zone at the slope toe was the smallest, while the plastic zone on both sides of the slip crack surface significantly decreased in size. The middle and upper part of the slope gradually transformed from two failure forms into tensile failure. In addition, the closer it was to the surface of the slope, the more discrete it was.

In summary, as the NPR cable anchorage length increased, the plastic failure scope became progressively lower, while the failure mode changed from shear failure and tensile failure to single failure. This indicated that the reinforcement effect of NPR anchor cable utilization on the slope was relatively apparent. Consequently, the effect would be more significant as the anchorage length increase. When the anchorage length was $25 \mathrm{~m}$, the reinforcement effect was the most successful.

\subsubsection{Analysis of slope safety factor}

The slope safety factor was obtained through numerical simulation and the results are presented in Table 17. The relation curve between safety factor and anchorage length is presented in Fig. 23. 
Table 17. Corresponding table of slope safety factor - anchorage length.

\begin{tabular}{cccccccc}
\hline Anchorage length $\square \mathrm{m} \square$ & - & 5 & 10 & 15 & 20 & 25 & 30 \\
\hline Slope safety factor & 1.28 & 1.30 & 1.31 & 1.31 & 1.32 & 1.31 & 1.31 \\
\hline
\end{tabular}

Compared to the case without reinforcement measures, the safety factor of slope increased and the slope was more stable after the reinforcement with NPR anchor cable. According to the curve graph of the relation between the slope safety coefficient and the anchorage length, the slope safety coefficient increased as the anchorage length increased, not following a simple direct proportional relation. When the anchorage length was $5 \mathrm{~m} \sim 20 \mathrm{~m}$, the safety coefficient increased as the anchorage length increased, followed by value drop and stable values at $20 \mathrm{~m} \sim 30 \mathrm{~m}$ stage. It would not be difficult to observe from the curve that when the anchorage length was $20 \mathrm{~m}$, the slope safety factor was the highest and the stability was improved, indicating that the reinforcement effect was the most successful.

\section{Conclusions}

This work used FLAC3D software to simulate the slope of Daye ancient copper mine site. Under the same condition of incident angle and preload, the slope reinforcement of NPR anchor cable with different anchorage length was simulated. The variation law of slope strain, stress and axial force of anchor cable, the variation and distribution characteristics of shear strain rate and plastic zone, as well as the variation law of stress of NPR anchor cable, were analyzed. Moreover, the anchorage characteristics of different anchorage lengths were analyzed. The main contents are as follows: (1) Through displacement change comparisons and analysis of the slope under the conditions of reinforcement without reinforcement measures and different anchor lengths, the displacement apparently decreased after reinforcement. As the anchorage length increased, the total displacement of strengthened area decreased, moving afar from the strengthened area. The displacement decreased with a decelerating rate and the efficiency of reinforcement gradually decreased. (2) Through the relationship analysis between anchorage length and axial force of the NPR cable, it could be obtained that the axial force was mainly distributed within the $0 \sim 5 \mathrm{~m}$ part near the free end. As the anchorage length increased, the distribution of the larger axial force was basically unchanged. The anchorage length increase could not effectively reduce the distribution position of the higher axial force. (3) Comparative analysis was conducted on the change characteristics of slope stress. After the application of NPR anchor rope for slope reinforcement, the distribution of main stress did not significantly change as the anchorage length increased, while the stress release was low within the reinforcement area. This indicated that the main stress of slope could not change through anchorage length increase. (4) The variation characteristics of shear strain rate and plastic zone under different conditions were compared and analyzed. The shear strain rate was relatively high at the slope slide crack face, while the plastic zone scope shrank after the slope was reinforced with NPR anchor cable. As the anchor length of NPR anchor cable increased, the plastic failure scope became lower, leading to change from shear and tension failures to single failure. (5) According to the calculation 
results of the safety factor, it could be concluded that the safety factor of slope basically increased as the anchorage length increased, reaching the peak value when the anchorage length was approximately $20 \mathrm{~m}$. The slope was the most stable and the reinforcement effect of NPR anchor cable was the most successful.

\section{Reference}

Fan G M, Lv H D (2019) Factors Affecting Slope Stability of Open-pit Metal Mines and Prevention Measures. World Nonferrous Metals, (15):88+90.

Zhang X W, Tian B, Lu X C, et al (2019) Study of Stability and Influencing Factors of Flexural Slope of Abutment of Jinsha Hydropower Station. J of China Three Gorges Univ. (Natural Sciences) 41 (03):21-25.

Xie T C, Liu H Y (2019) Stability Analysis of Rock Slope with Multiple Cracks. Mining Research and Development 39 (06):53-57.

Wang W T, Liu Y Y, Shi E L (2019) Drilling and construction of anchor cable technology in fractured mountain area. Building Technology Development 46(20): 88-90.

Li Y S (2014) Lattice frame anchor structure applied in the treatment of slope. Gan Su Geology, 23(03): 79-81+89.

Song J, Liang J, Shi S W, et al. (2018) Modelling test on the mechanical properties of pre-stressed lattice framed anchor structure. Journal of Geomechanics 03, 432-438.

Guo Z S, Zheng J J, Cui L, et al. (2015) Comparative analysis of mechanical properties and support effects of polyester bolt and traditional steel bolt. Chinese Journal of Geotechnical Engineering S1: 202206.

Tao Z G, Yang W, Liu W X, et al. (2018) Anchor cable of high constant resistance of landslide monitoring: static tensile and engineering application. Journal of Yangtze River Scientific Reaserch Institute 35(06): 128-134.

Tao Z G, Zhang H J, Yin L J, et al. (2017) Numerical modeling of cracking for the Jietai temple ancient landslide with the combined finite-discrete element method. Hydrogeology \& Engineering Geology44(03): 105-112.

Jing H W, Yin Q, Zhu D, et al.(2019) Experimental study on the whole process of instability and failure of anchorage structure in surrounding rock of deep-buried roadway. Journal of China Coal Society: 1-12 [2020-02-04]. https: // doi.org/10. 13225 / j. cnki. jccs 0637.

Chen X G, Tao Z G, Gui Y, et al. (2011) Reaserch of sliding force warning model based on remote real-time monitor landslide system. Metal Mine (12): 127-131. 
Tao Z G, Zhang B, He M C. (2011) Reaserch on mechanism and monitoring and early-warning technology of landslide in Luoshan mining area. Chinese Journal of Rock Mechanics and Engineering 30(S1): 29312937.

He M C, Li C, Gong W L (2015) Elongation and impacting experimental system for bolts with constant resistance and large deformation and finite element analysis. Chinese Journal of Rock Mechanics and Engineering 34(11): 2179-2187.

Li C, He M C, Gong W L (2015) Analysis on kinetic features of constant resistance high deformed bolt under different impact velocity. Coal Science and Technology 43 (09): 53-58.

Li C, He M C, Gong W L (2016) Analysis on impact dynamics of negative Poisson's ratio effect of anchor bolt with constant resistance and large deformation. Journal of China Coal Society 41(06): 1393-1399.

He M C, Li C, Gong W L (2016) Support principles of NPR bolt/cable and control techniques of large deformation. Chinese Journal of Rock Mechanics and Engineering 35(8) $₫ 1513-1529$.

Tao Z G, Zhao S, Zhang M X, et al.(2018) Numerical simulation research on mechanical properties of constant resistance bolt/cable with large deformation. Journal of Mining and Safety Engineering 35(01): 40-48.

Lv Q (2018) Study on mechanical characteristics of NPR anchor under static tension condition. Dissertation, China University of Mining \& Technology, Beijing.

Lv Q, Tao Z G, Li Z H, et al. (2018) Elasto-plastic mechanics analysis of large deformation anchor .Chinese Journal of Rock Mechanics and Engineering 37 (04):792-800.

Tao Z G, Li M N, Pang S H, et al. (2020) Reaserch on mechanical property and engineering application of cable with high constant resistance and large deformation. Journal of Mining Science and Technology (01):1-11.

\section{Declaration}

Availability of data and materials: We declared that materials described in the manuscript, including all relevant raw data, will be freely available to any scientist wishing to use them for non-commercial purposes, without breaching participant confidentiality.

Competing interests: No conflict of interest exists in the submission of this manuscript, and manuscript is approved by all authors for publication. 
Funding: This paper is supported by the National Natural Science Foundation of China (NSFC) (41941018) and Science and Technology Plan of Gansu Province (19ZD2GA005).

\section{Authors' contributions:}

TAO Zhigang Gcontributed to the conception of the study;

TAO Zhigang, DENG Fei, performed the experiment;

TAO Zhigang, DENG Fei, WANG Zhicai contributed significantly to analysis and manuscript preparation;

TAO Zhigang, DENG Fei, LI Mengnan performed the data analyses and wrote the manuscript;

QIAO Xiaobing, WANG Zhicai, XU Shengxin helped to perform the analysis with constructive discussions.

Acknowledege: This paper is supported by the National Natural Science Foundation of China (NSFC) (41941018) and Science and Technology Plan of Gansu Province (19ZD2GA005).

\section{Figures}

\section{Figure 1}

Distributions of main parts of No. VII ore body site 

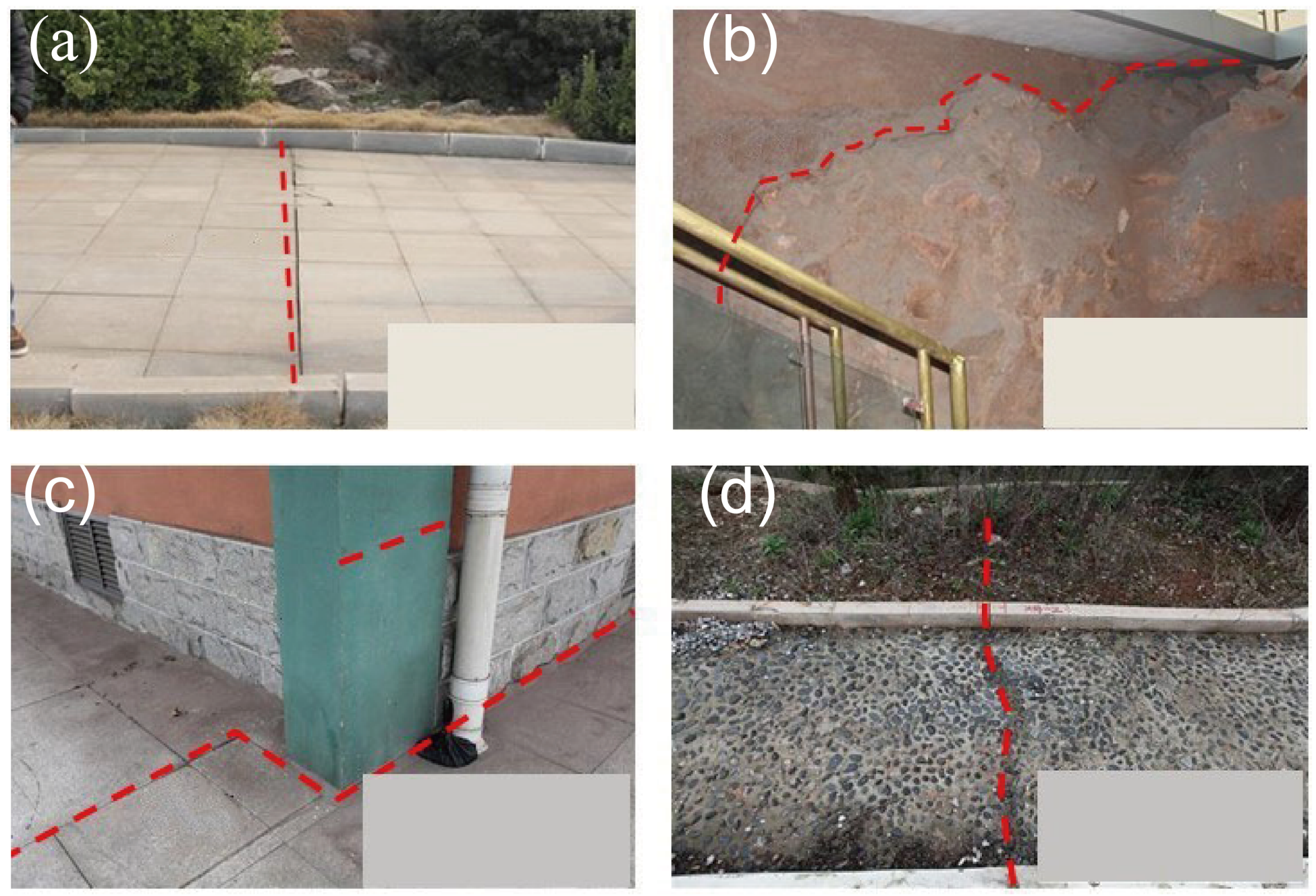

Figure 2

Distribution characteristics of internal and external cracks at Museum building (a) Road outside the site, (b): South wall of site, (c): Wall cracks at northwest corner of site, (d): museum exterior. 


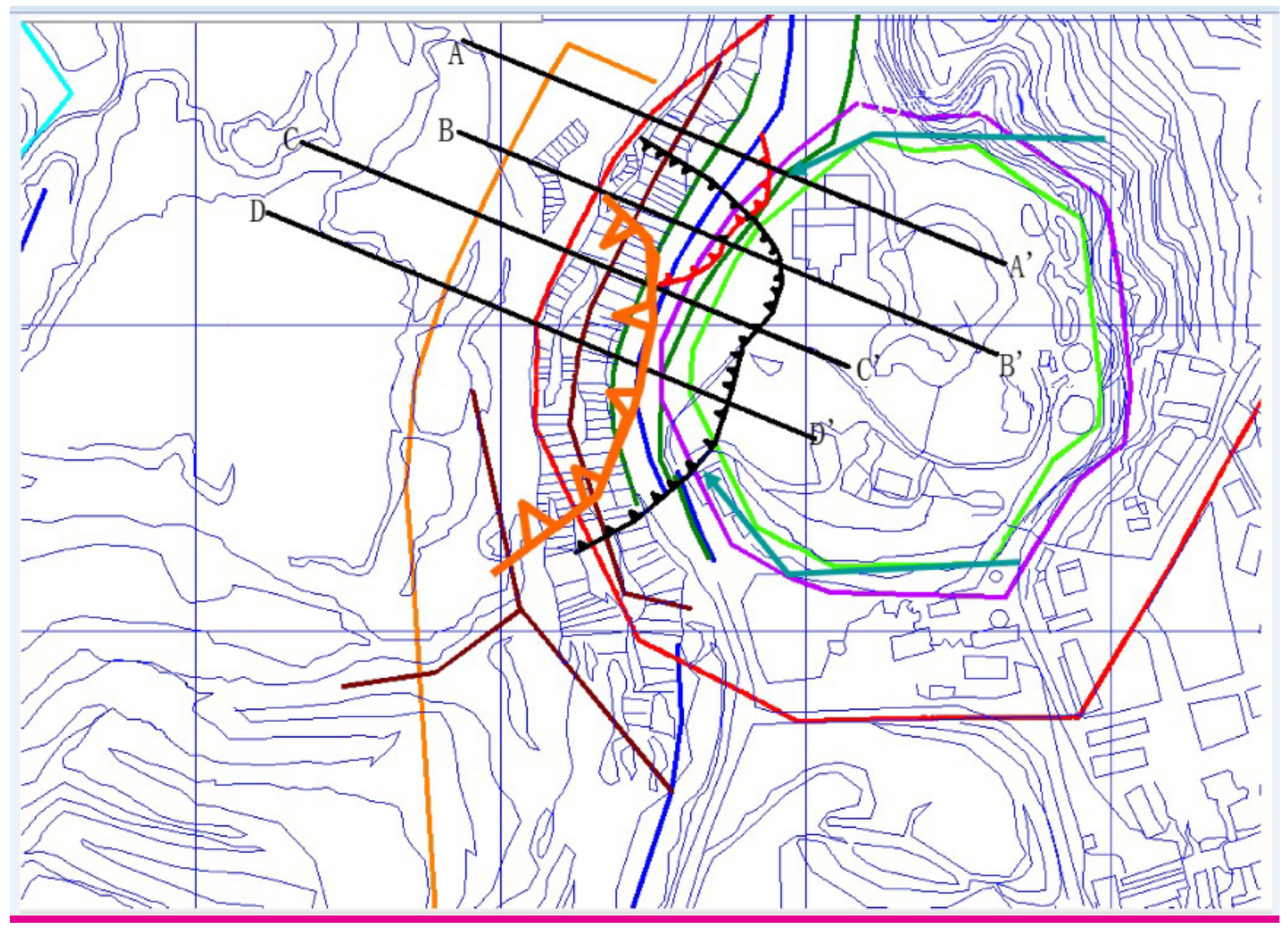

Figure 3

Landslide body and location of each section 
(a)

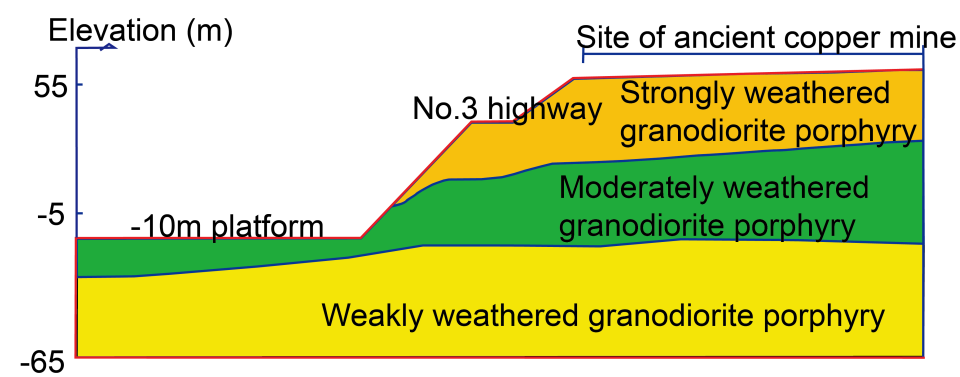

(c)

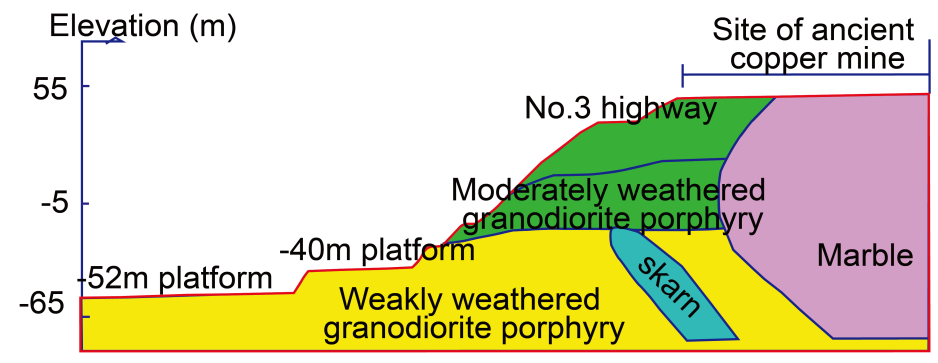

(b)

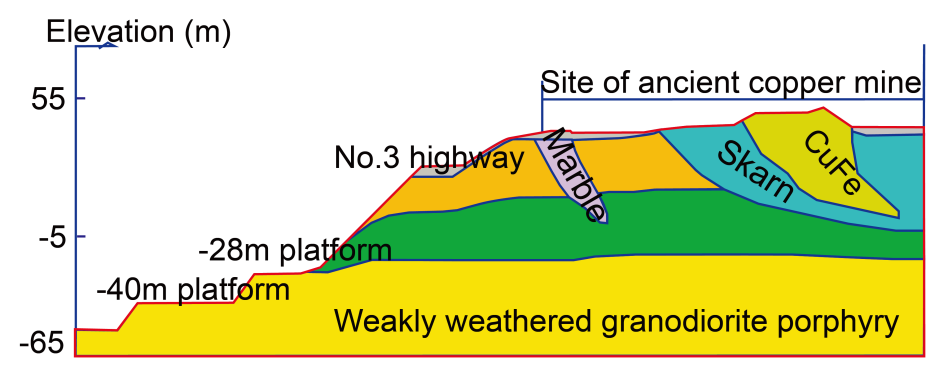

(d)

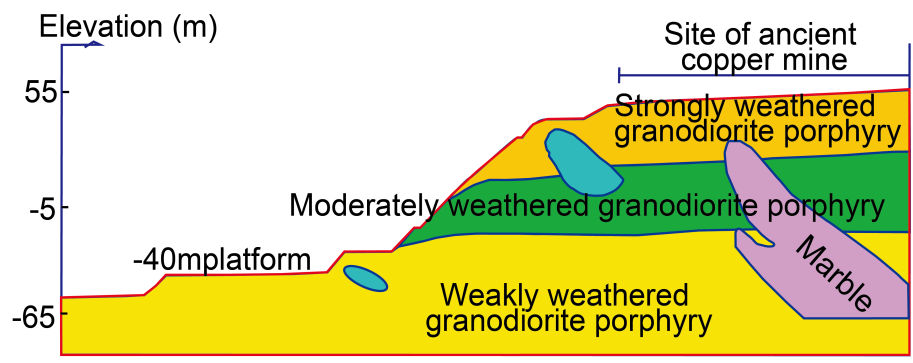

\section{Figure 4}

Elevation geological section of each section 

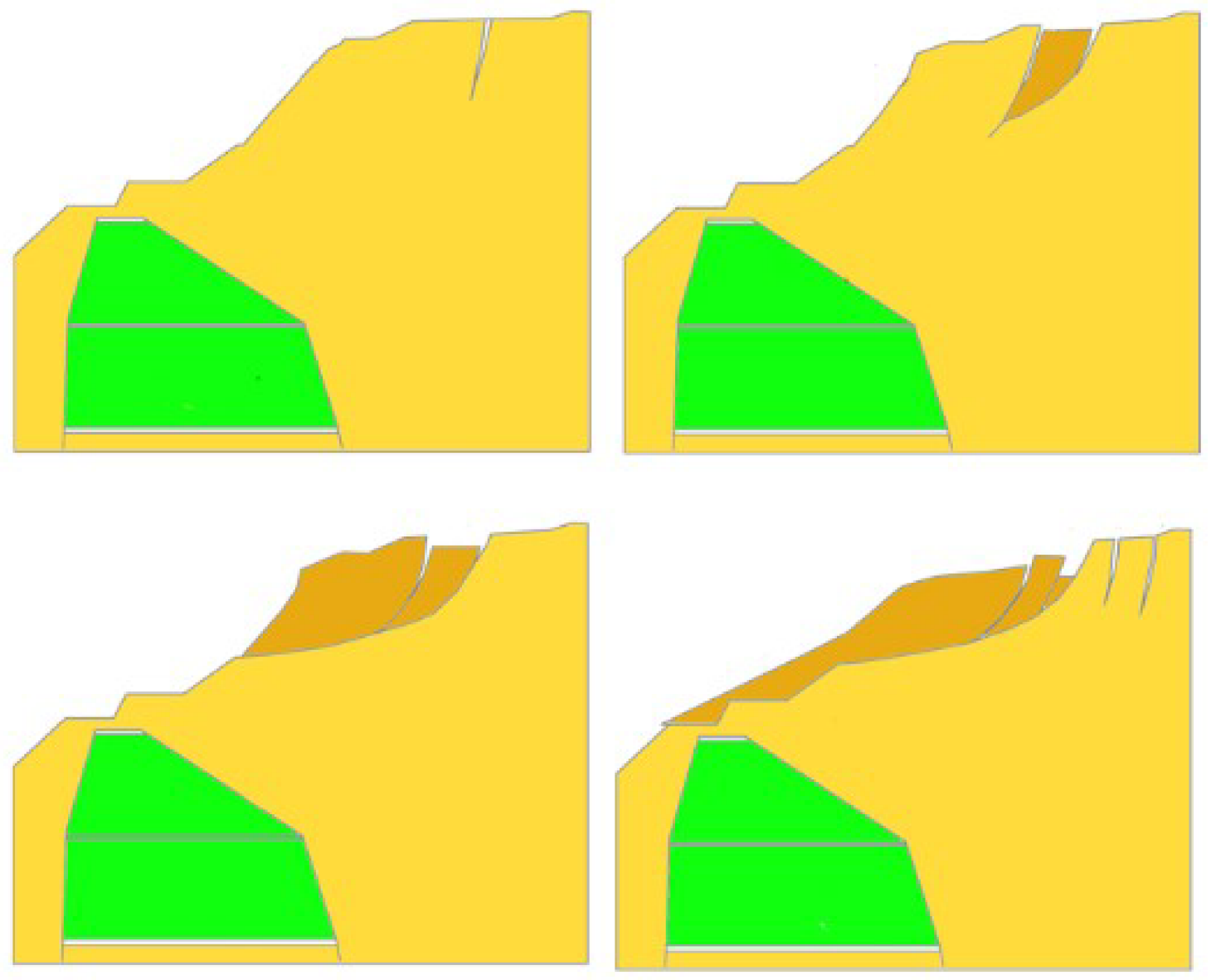

Figure 5

Landslide mechanism diagram 


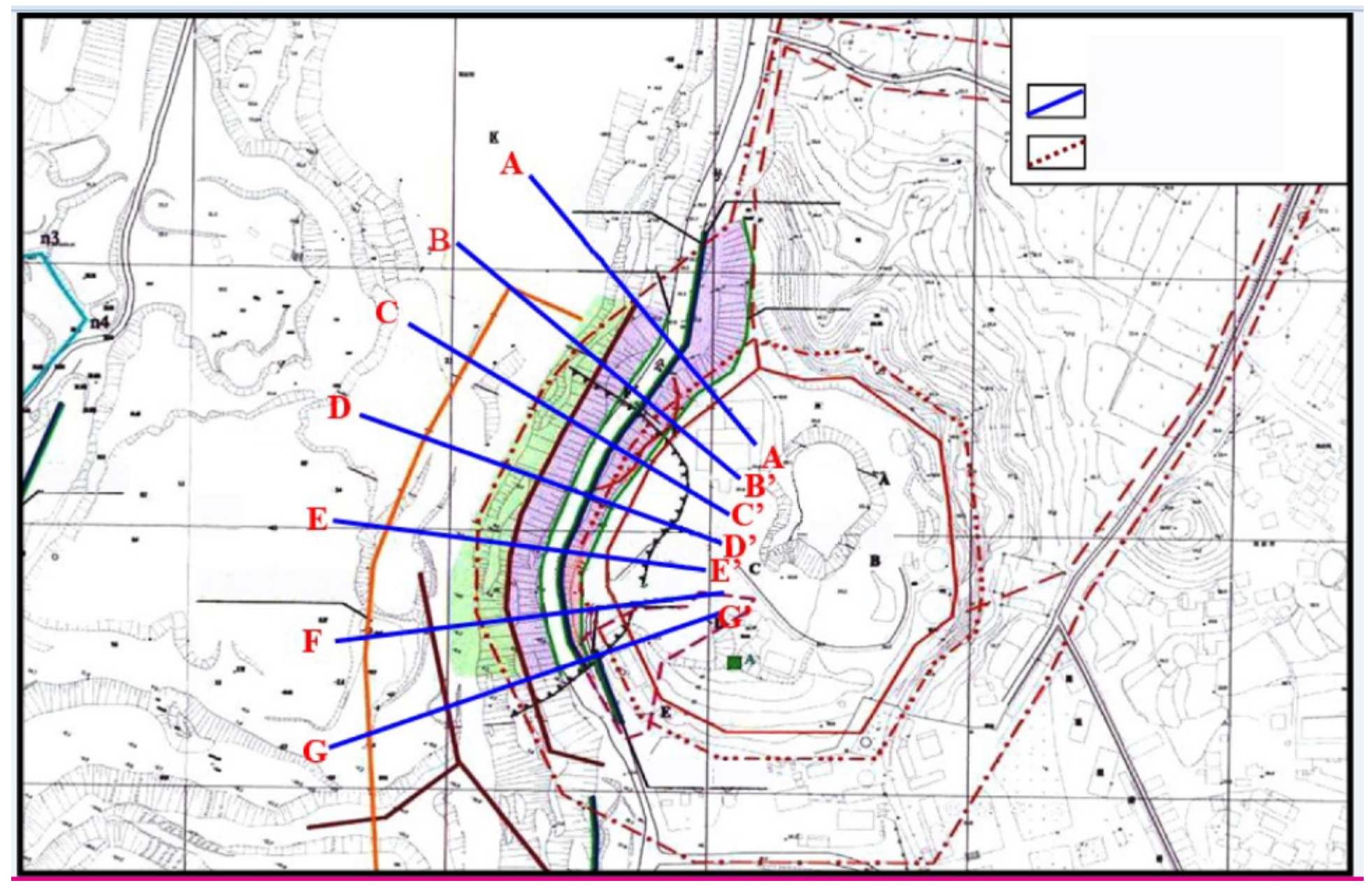

Figure 6

Locations of each site slope section

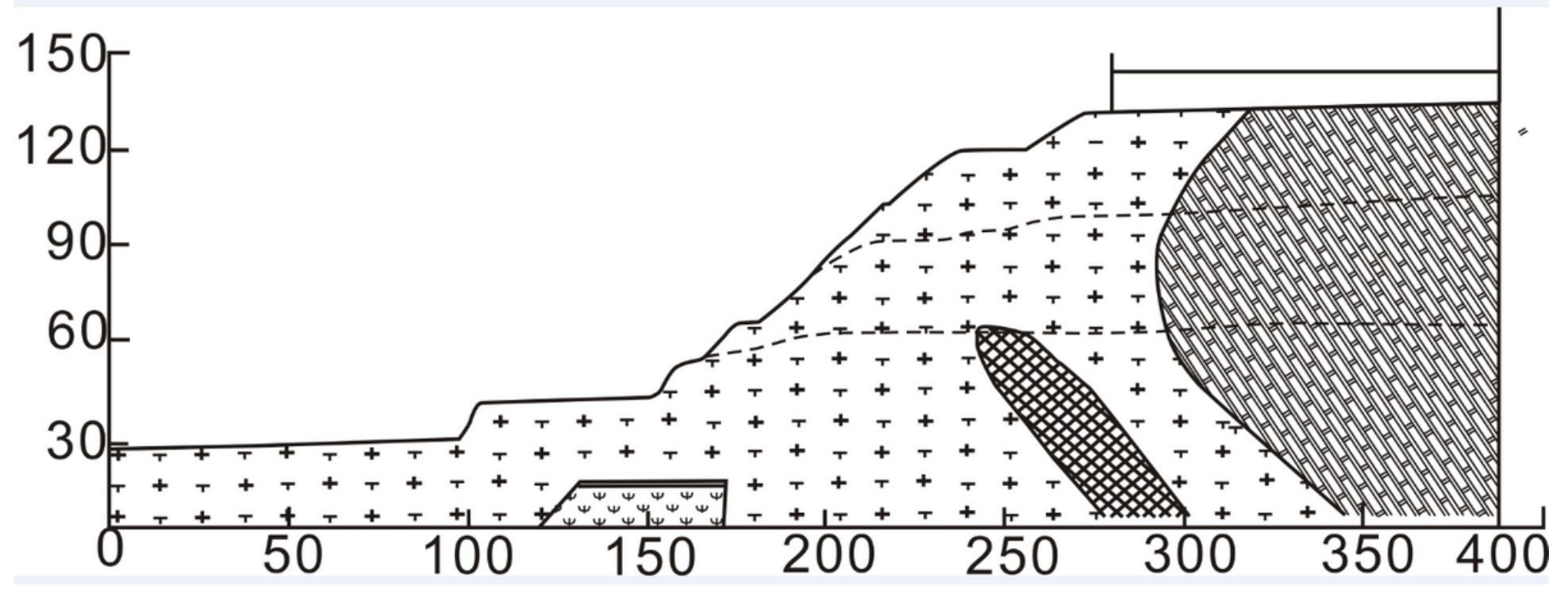

Figure 7 
C-C' section view of site slope A: Quaternary stratigraphic soil, B: Strongly weathered syenite porphyry, C: Moderately weathered syenite porphyry, D: Weakly weathered diorite

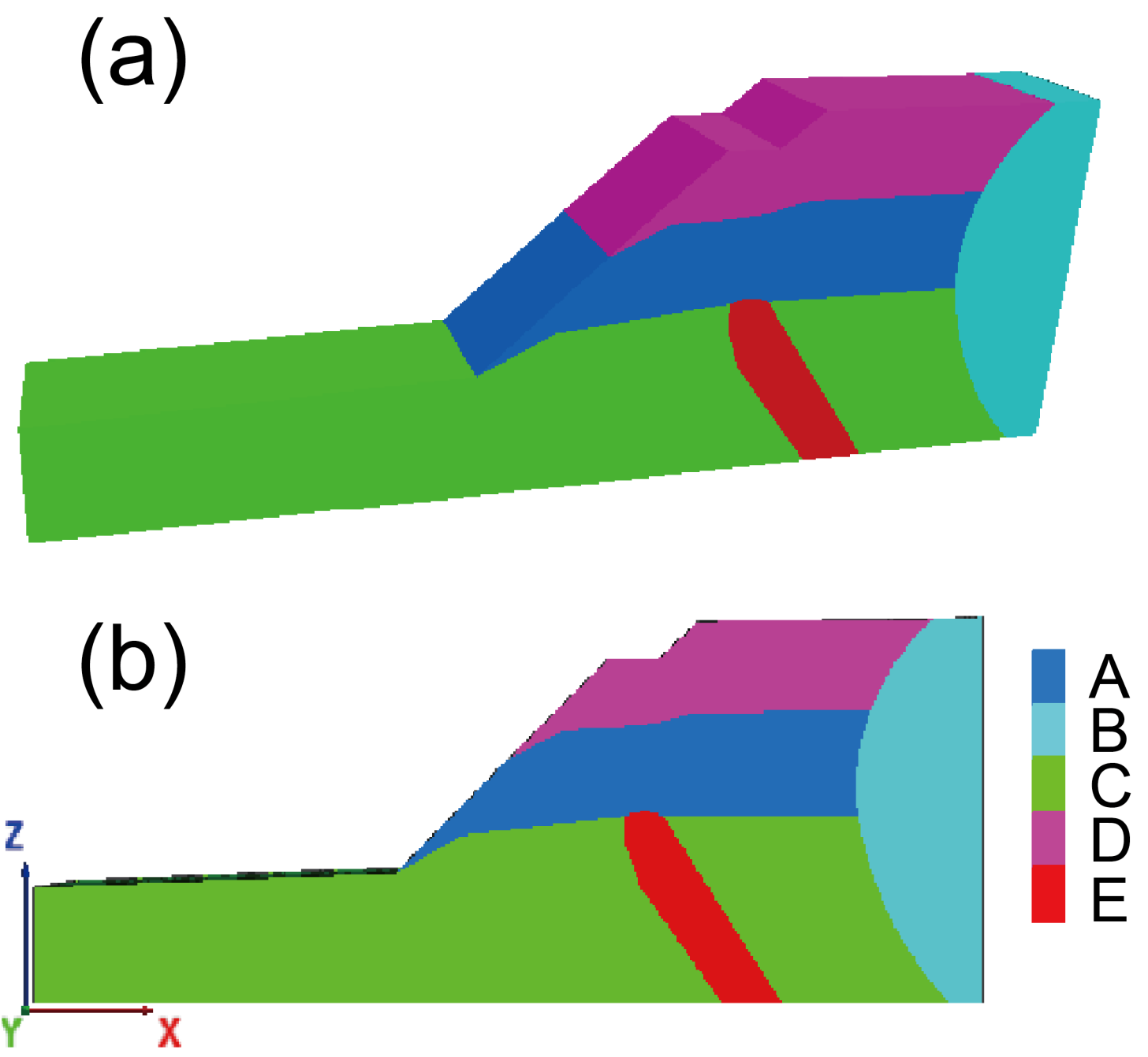

\section{Figure 8}

Model of C-C' section A: Moderately weathered diorite porphyry, B: Marble, C: Weakly weathered diorite, D: Weakly weathered diorite E Skarn 
(a)
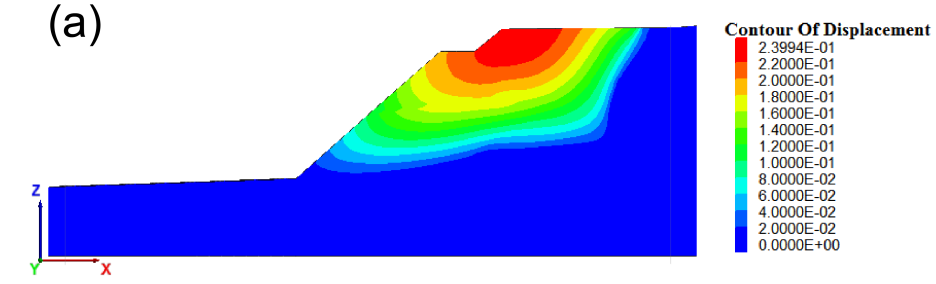

(c)
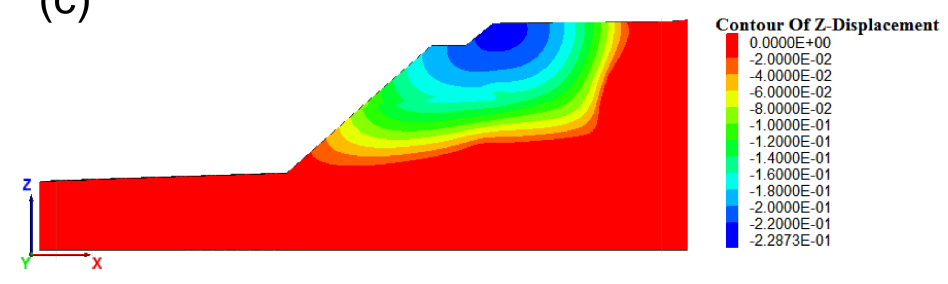

(e)

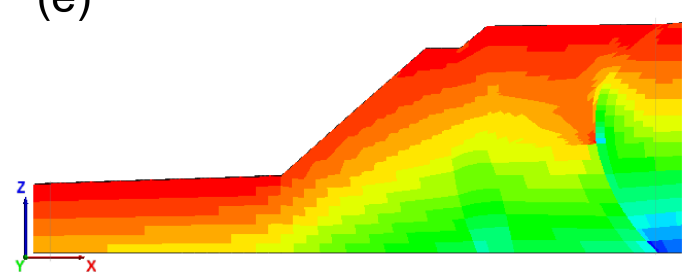

(b)

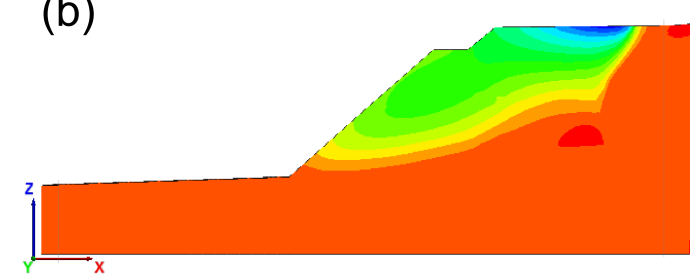

Contour of X-Displacement

$3.8580 \mathrm{E}-03$
$0.0000 \mathrm{E}+00$
$-1000 \mathrm{E}$

$-1.0000 \mathrm{E}-02$

$-2.00000-02$
$-3.0000 \mathrm{E}-02$

-4.0000E- 02

$-5.0000 \mathrm{E}-02$
$-6.000 \mathrm{E}-0.02$

$-7.0000 \mathrm{E}-02$

$-8.0000 \mathrm{E}-02$

$-1.0000 \mathrm{E}-01$

$-1.1000 \mathrm{E}-01$
$-1.2000 \mathrm{E}-01$

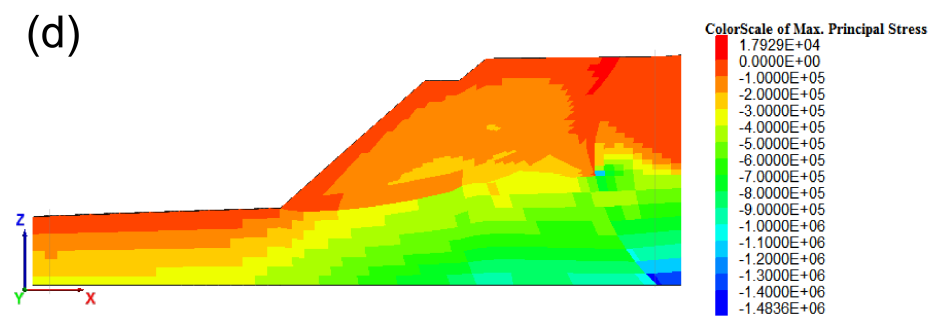

(f)

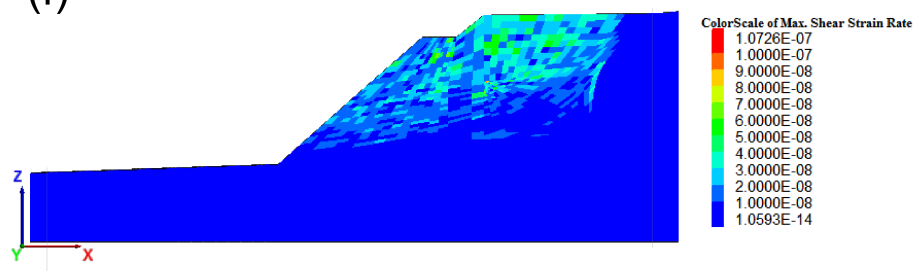

Figure 9

Stress field nephogram of C-C'section in initial equilibrium (a) Total displacement, (b) X-displacement, (c) Z-displacement, (d) Maximum principal stress, (e) Minimum principal stress, (f) Shear strain rate 
(a)

Anchor plate

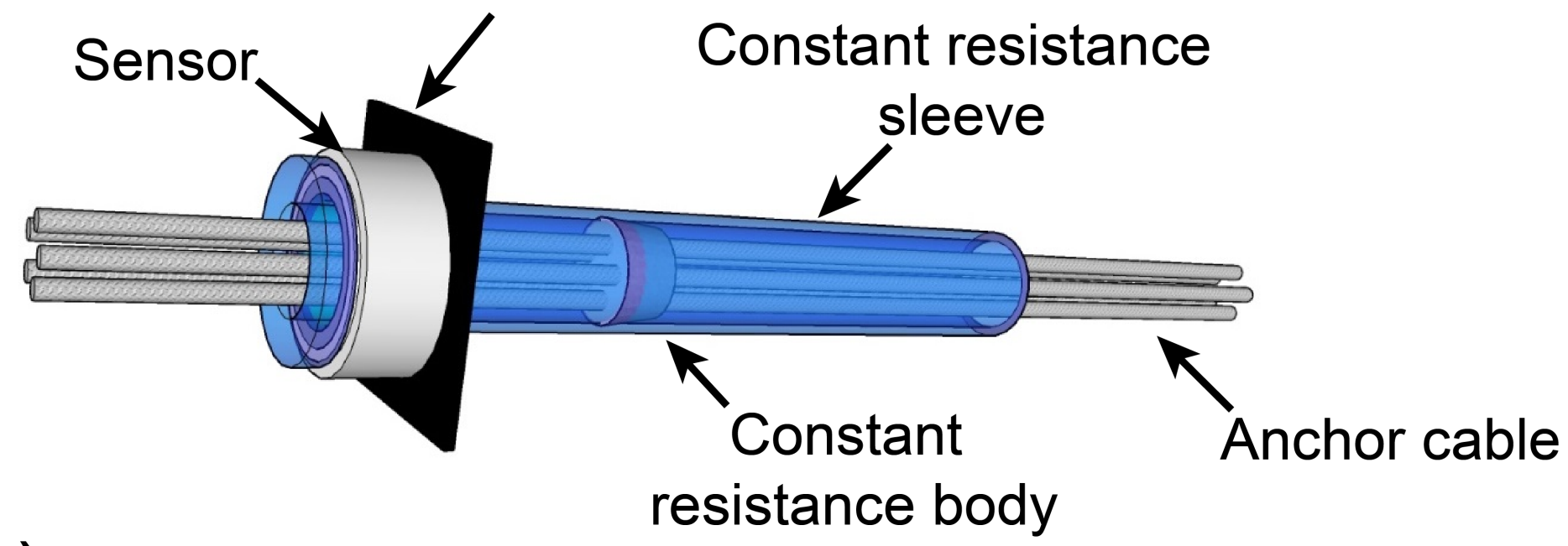

(b)

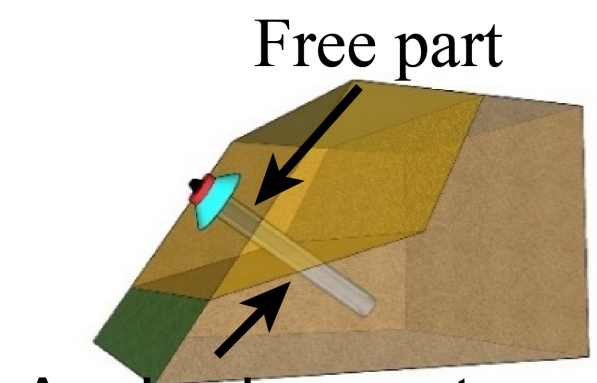

Anchoring part

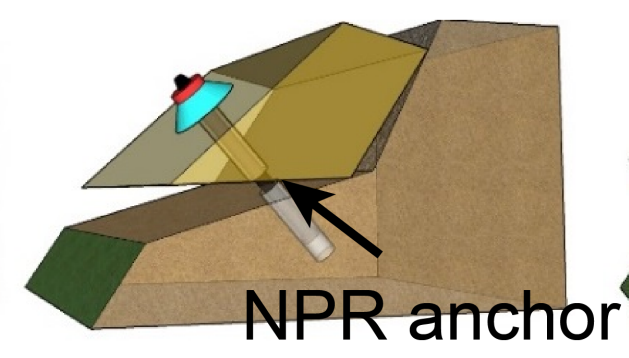

During failing

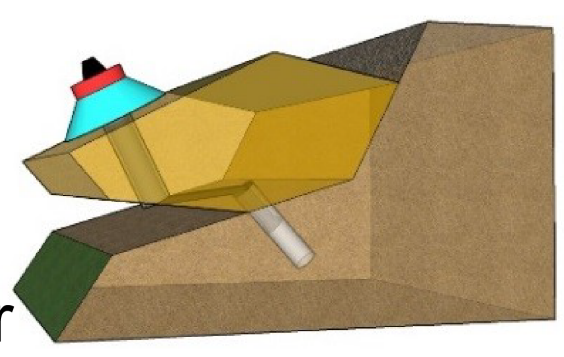

After failing

Figure 10

Sketch diagram of NPR bolt (a) Characteristics of NPR anchor cable structure, (b) Principle of NPR anchor cable large deformation control 


\section{(a)}

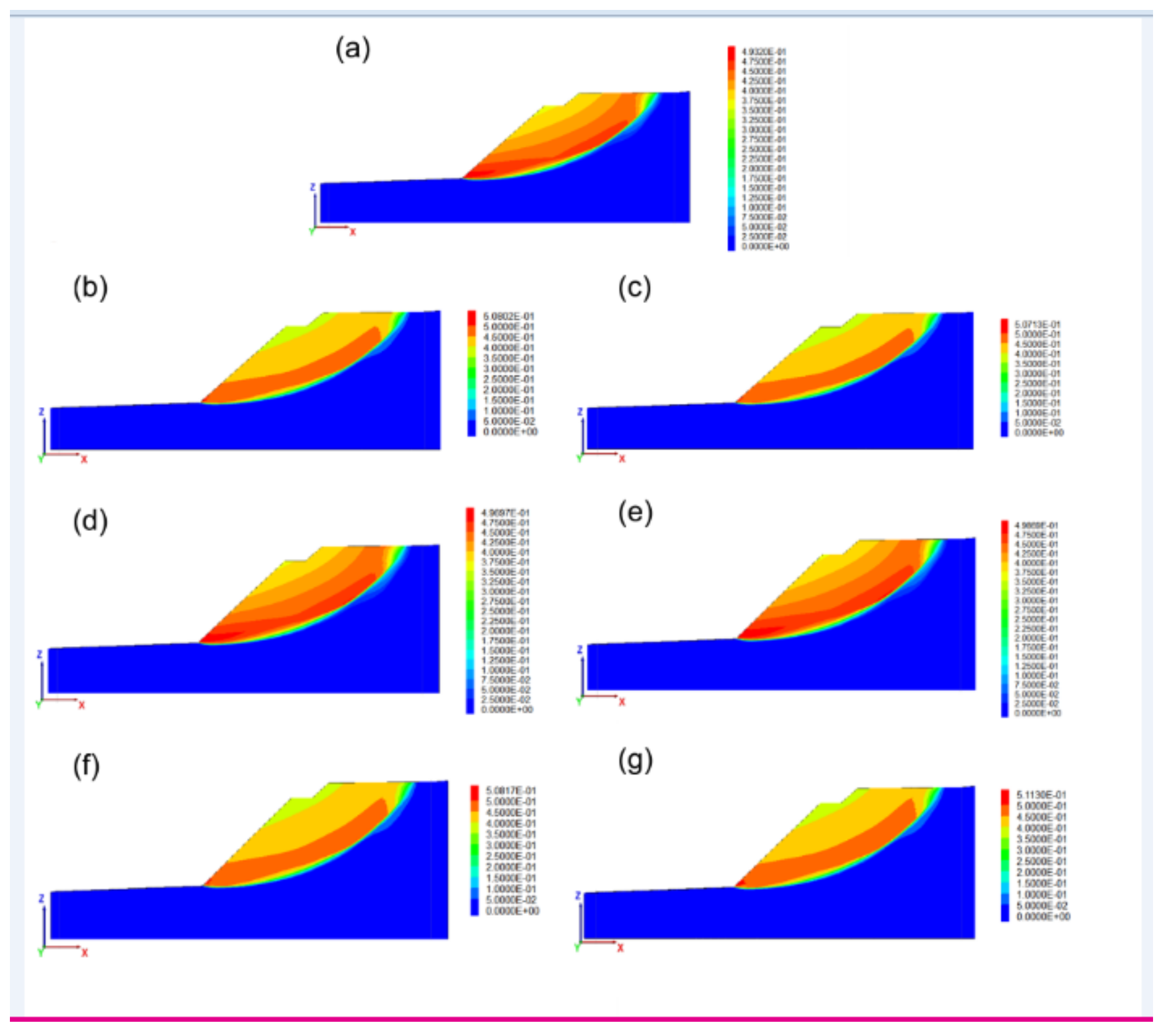

\section{Figure 11}

Total displacement nephogram of C-C'section of site slope under different conditions (a) without reinforcement, (b) with anchorage length of $5 \mathrm{~m}$, (c) with anchorage length of $10 \mathrm{~m}$, (d) with anchorage length of $15 \mathrm{~m},(\mathrm{e})$ with anchorage length of $20 \mathrm{~m},(\mathrm{f})$ with anchorage length of $25 \mathrm{~m},(\mathrm{~g})$ with anchorage length of $30 \mathrm{~m}$ 


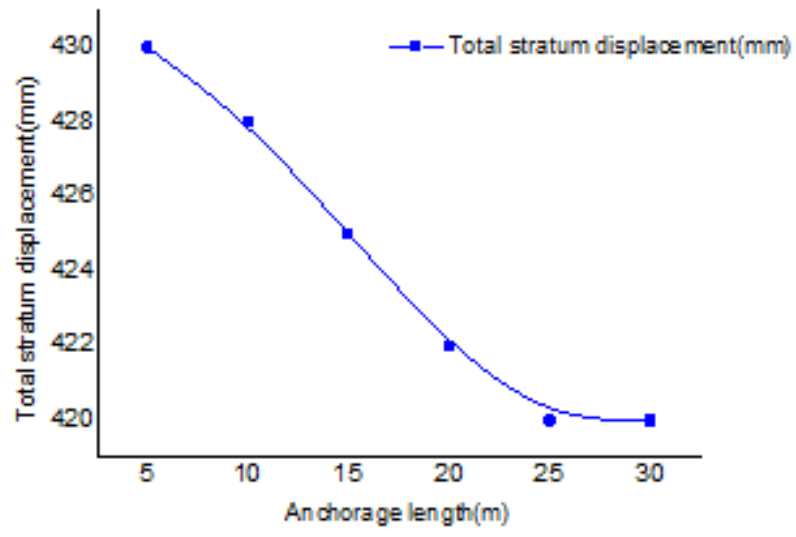

Figure 12

Relation graph of total displacement of reinforced area - anchorage length

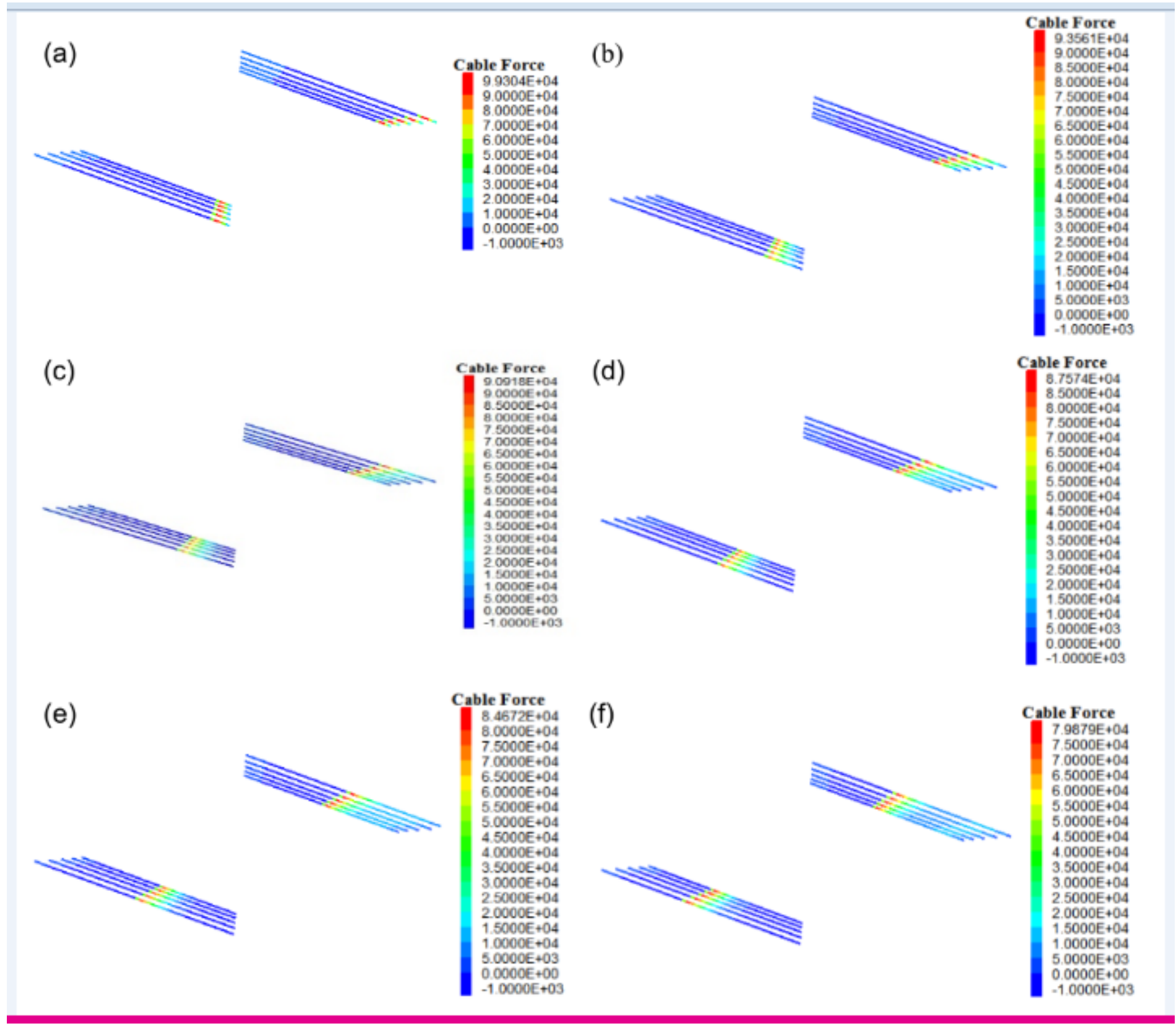


Figure 13

Axial force nephogram of NPR anchor cable under different conditions (a) with anchorage length of $5 \mathrm{~m}$, (b) with anchorage length of $10 \mathrm{~m}$, (c) with anchorage length of $15 \mathrm{~m}$, (d) with anchorage length of $20 \mathrm{~m}$, (e) with anchorage length of $25 \mathrm{~m}$, (f) with anchorage length of $30 \mathrm{~m}$
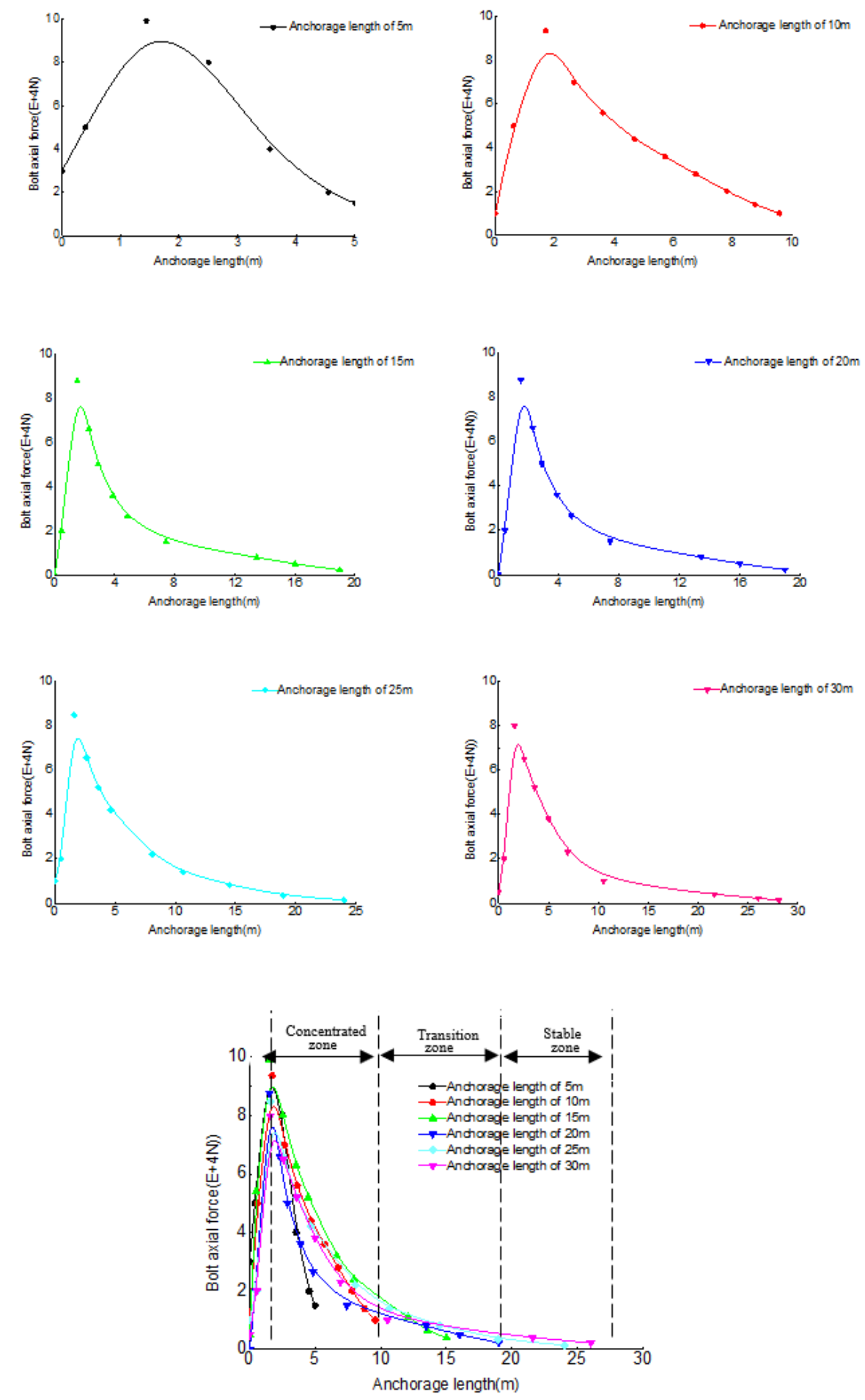

Figure 14 
Distribution graph of axial force distributed on anchorage section of NPR anchor cable

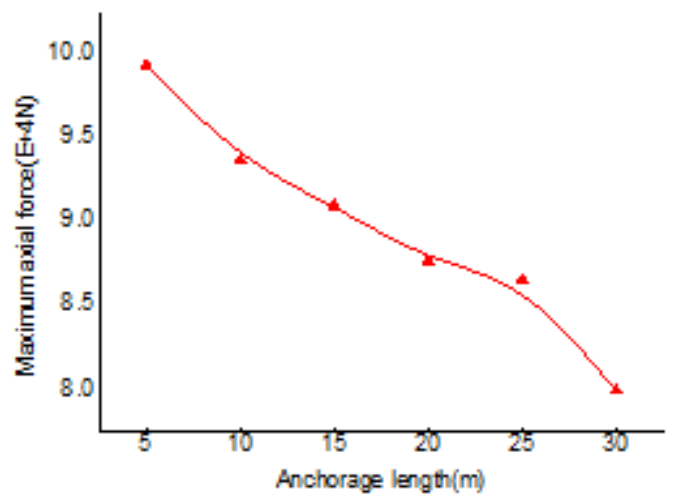

Figure 15

Relation graph of maximum axial force - anchoring section

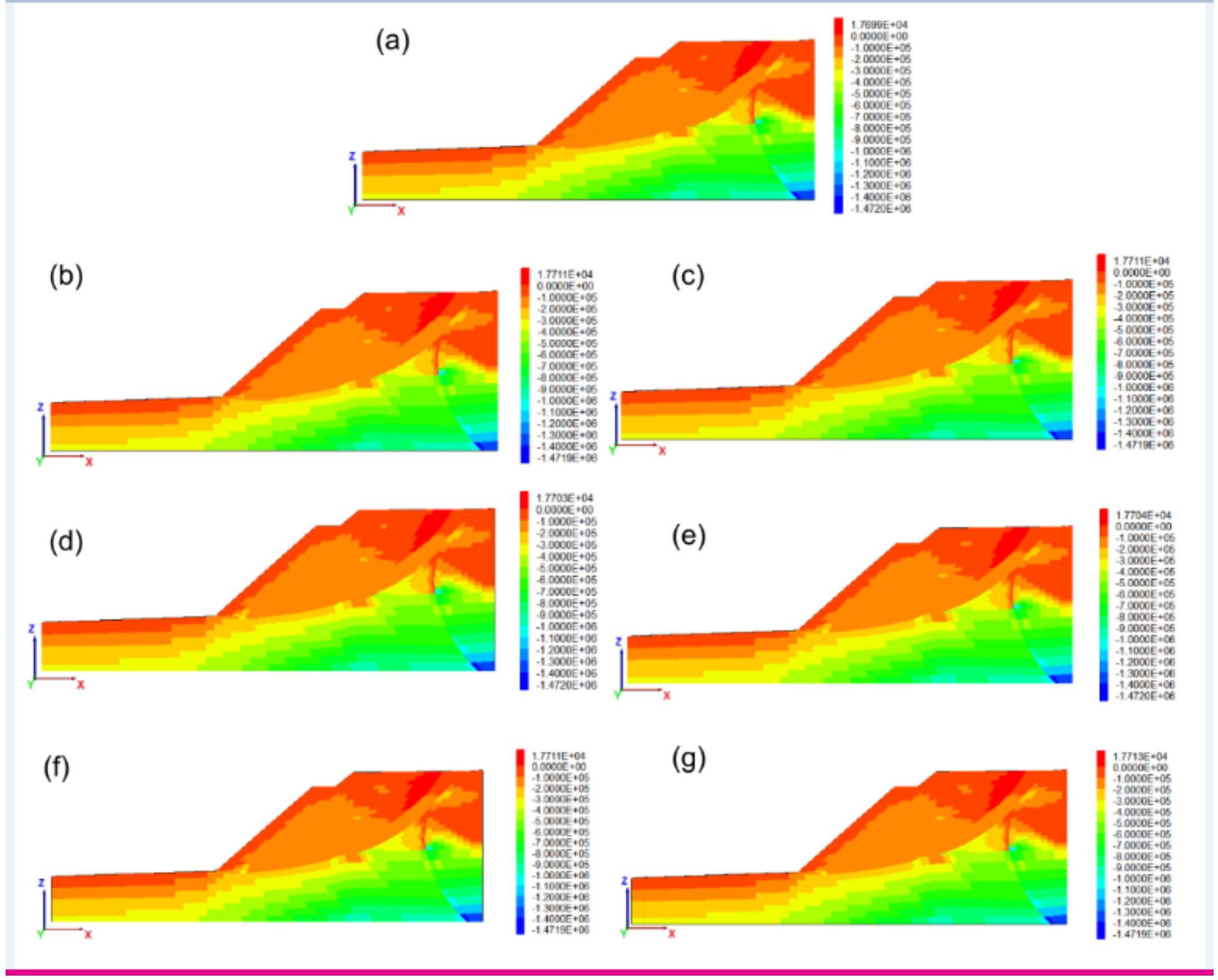


Figure 16

Maximum principal stress nephograms of C-C' section of site slope under different conditions (a) without reinforcement, (b) anchorage length of $5 \mathrm{~m}$, (c) anchorage length of $10 \mathrm{~m}$, (d) anchorage length of $15 \mathrm{~m},(\mathrm{e})$ anchorage length of $20 \mathrm{~m}$, (f) anchorage length of $25 \mathrm{~m} \mathrm{~g}$ anchorage length of $30 \mathrm{~m}$
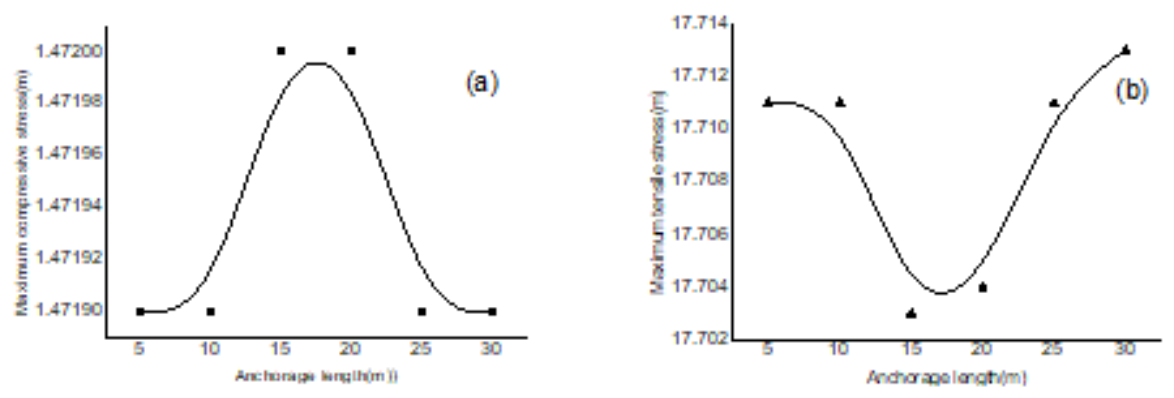

\section{Figure 17}

Distribution graphs of maximum principal stresses - anchorage lengths (a) Relationship curve between maximum compressive stress and anchorage length, (b) Relationship curve between maximum tensile stress and anchorage length 


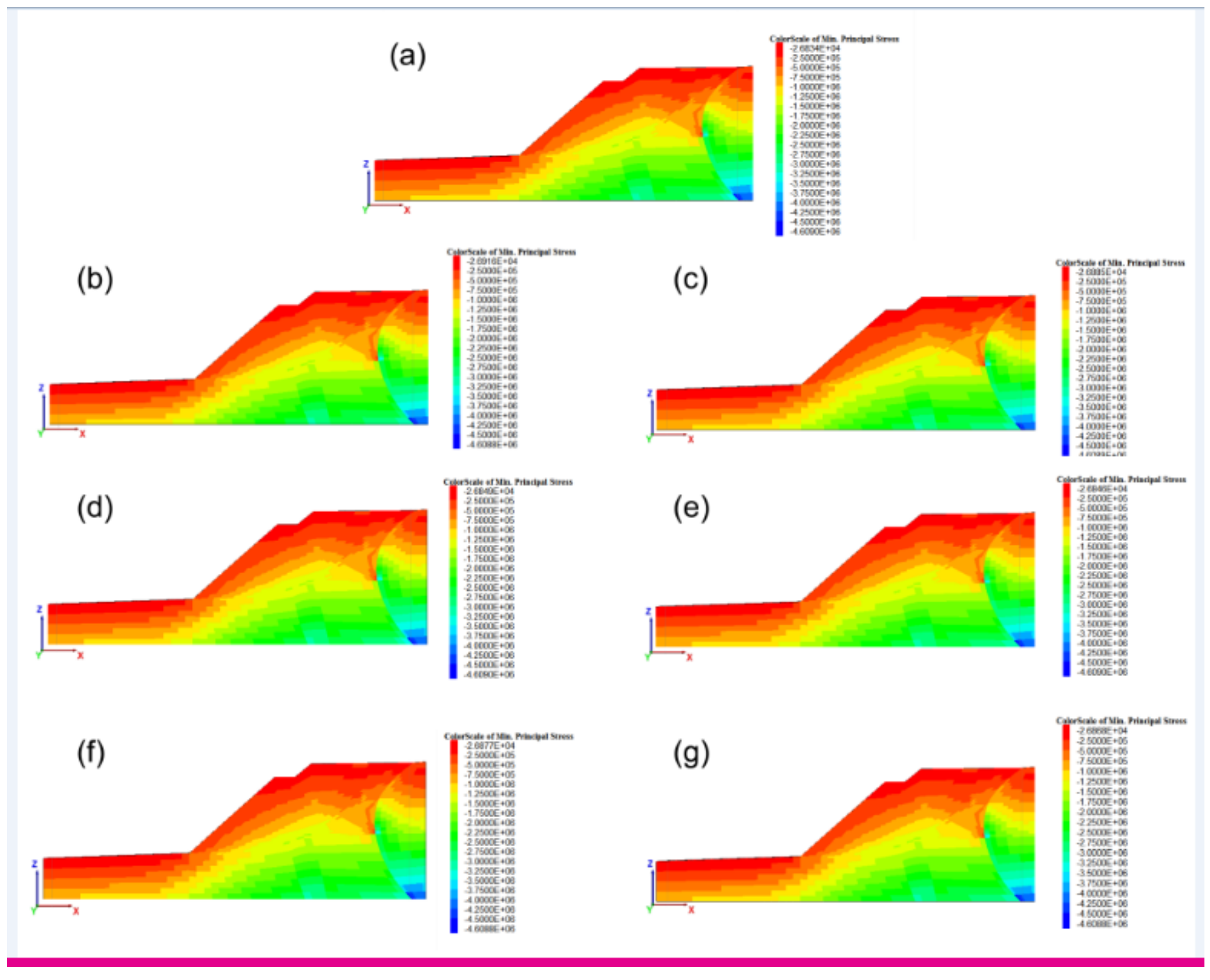

\section{Figure 18}

Minimum principal stress nephogram of C-C'section of site slope under different conditions (a) without reinforcement, (b) with anchorage length of $5 \mathrm{~m}$, (c) with anchorage length of $10 \mathrm{~m}$, (d) with anchorage length of $15 \mathrm{~m},(\mathrm{e})$ with anchorage length of $20 \mathrm{~m},(\mathrm{f})$ with anchorage length of $25 \mathrm{~m},(\mathrm{~g})$ with anchorage length of $30 \mathrm{~m}$
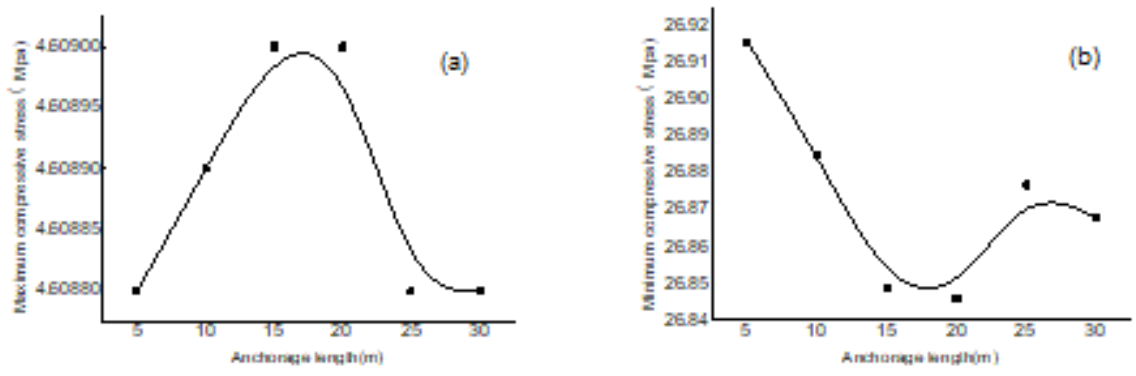


\section{Figure 19}

Distribution graph of minimum principal stress - anchorage length (a) Relationship curve between maximum compressive stress and anchorage length, (b) Relationship curve between minimum compressive stress and anchorage length

(a)

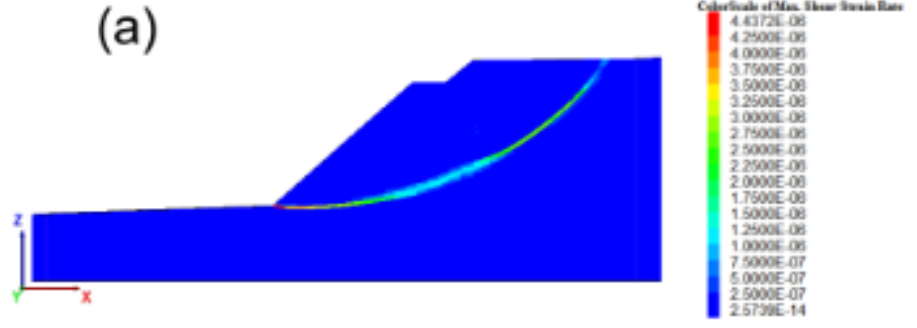

(b)

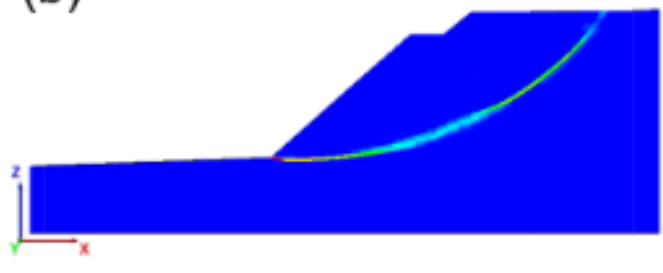

(d)

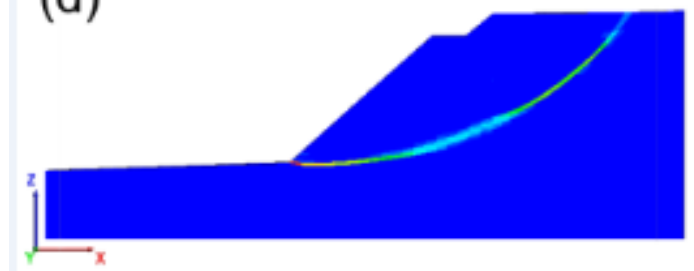

(f)

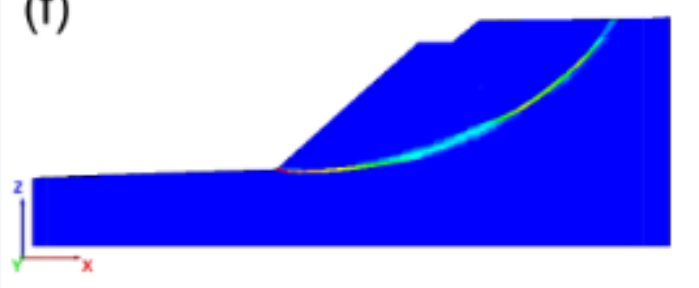

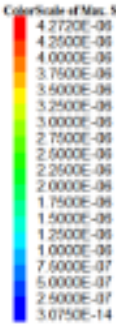

(c)

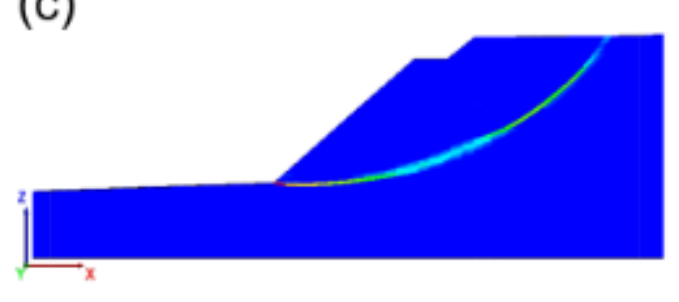

(e)

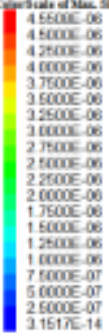

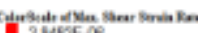

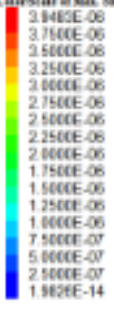

(g)
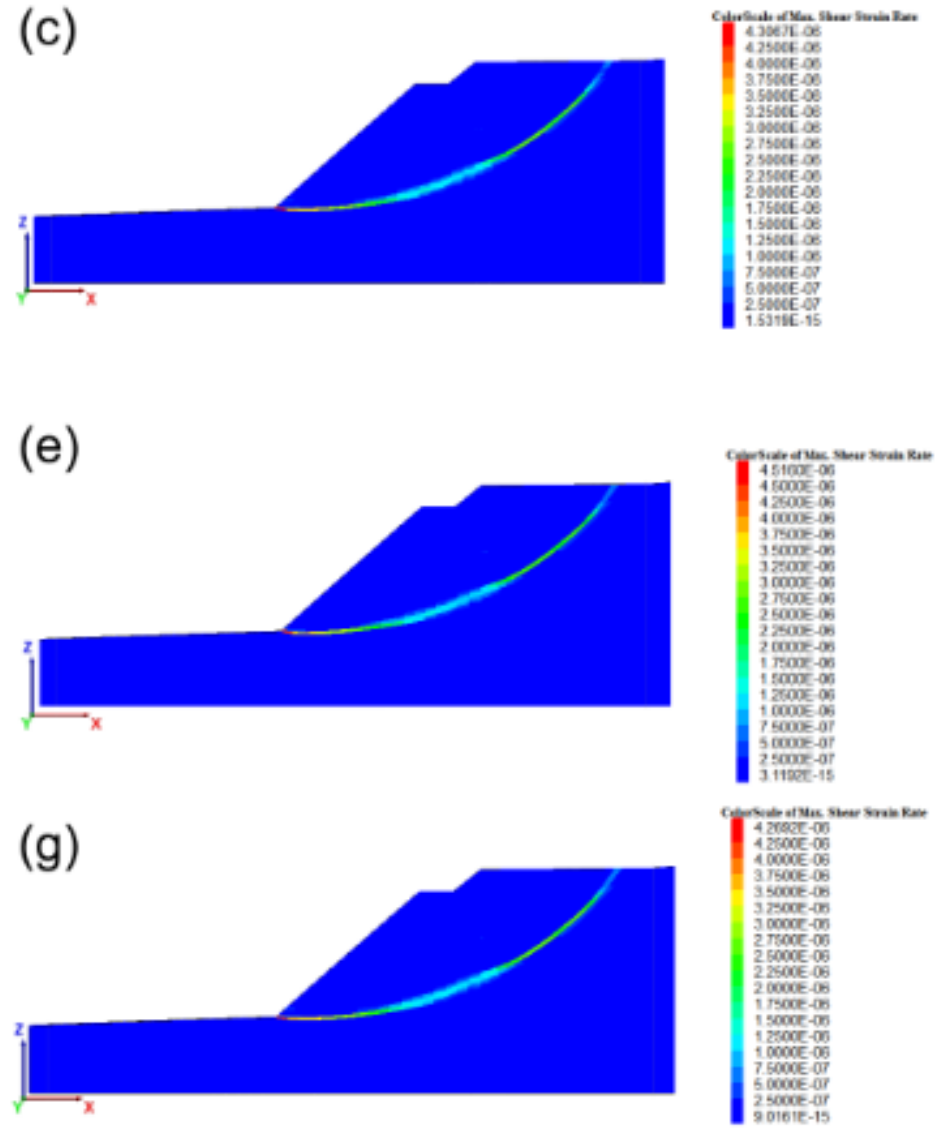

Figure 20

Shear strain rate nephogram of C-C'section of site slope under different conditions (a) without reinforcement, (b) with anchorage length of $5 \mathrm{~m}$, (c) with anchorage length of $10 \mathrm{~m}$, (d) with anchorage length of $15 \mathrm{~m}$, (e) with anchorage length of $20 \mathrm{~m}$, (f) with anchorage length of $25 \mathrm{~m}$, (g) with anchorage length of $30 \mathrm{~m}$ 

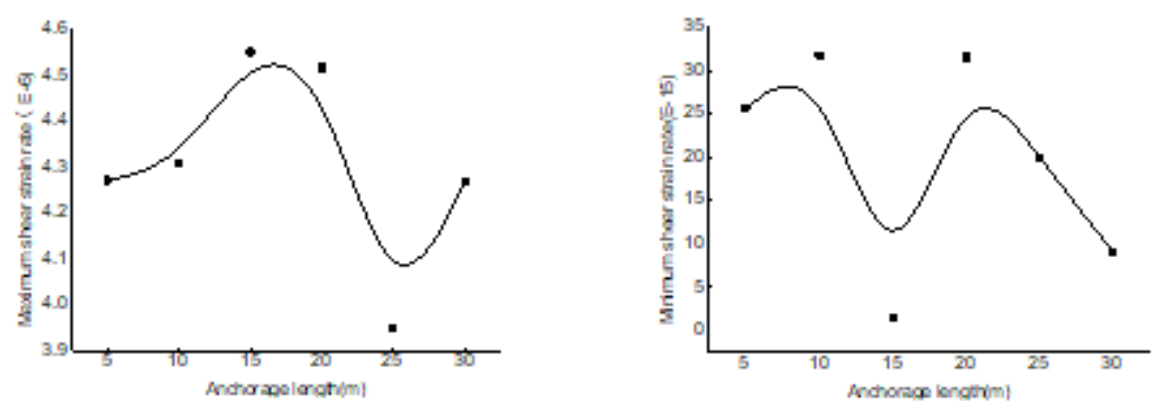

Figure 21

Distribution graph of the shear strain rate - anchorage length

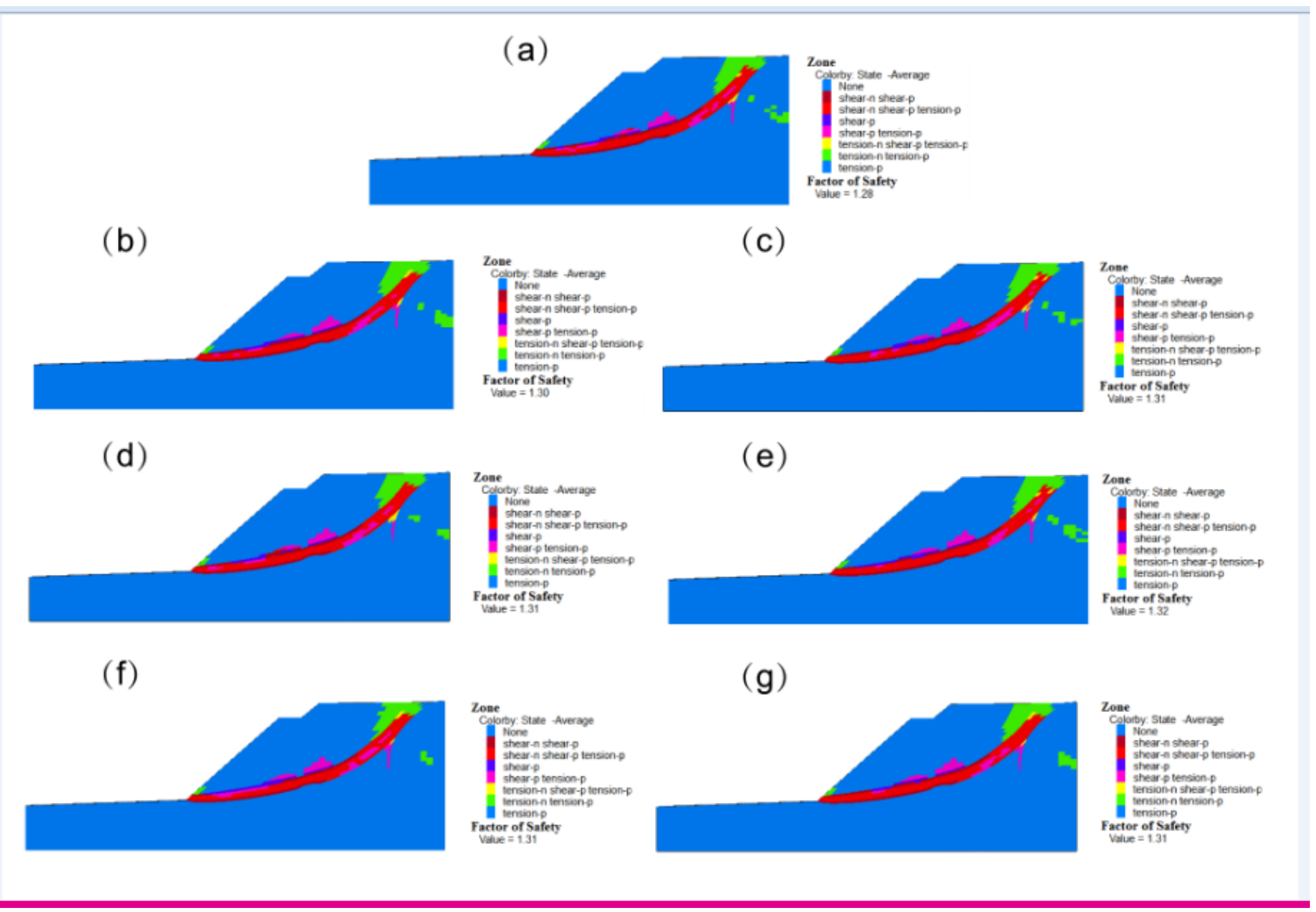

\section{Figure 22}

Plastic zone nephogram of C-C' section of site slope under different conditions (a) without reinforcement, (b) with anchorage length of $5 \mathrm{~m}$, (c) with anchorage length of $10 \mathrm{~m}$, (d) with anchorage length of $15 \mathrm{~m},(\mathrm{e})$ with anchorage length of $20 \mathrm{~m}$, (f) with anchorage length of $25 \mathrm{~m}$, (g) with anchorage length of $30 \mathrm{~m}$ 


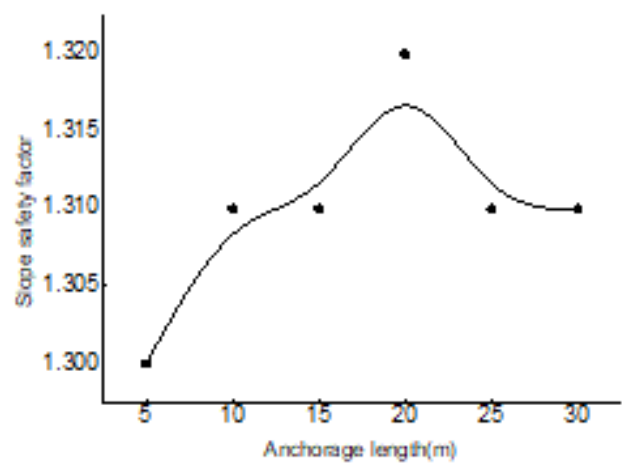

Figure 23

Distribution graph of the slope safety factor - anchorage length

\section{Supplementary Files}

This is a list of supplementary files associated with this preprint. Click to download.

- Fig.3legend.tif 